\title{
Early Mesozoic sedimentary-tectonic evolution of the Central-East Iranian Microcontinent: Evidence from a provenance study of the Nakhlak Group
}

Seyyedeh Halimeh Hashemi Azizi ${ }^{\mathrm{a}, \mathrm{b}}$, Payman Rezaee ${ }^{\mathrm{a},{ }^{*}}$, Mahdi Jafarzadeh ${ }^{\mathrm{c}}$, Guido Meinhold $^{\mathrm{b}, \mathrm{d}}$, Seyyed Reza Moussavi Harami ${ }^{\mathrm{e}}$, Mehdi Masoodi ${ }^{\mathrm{a}}$

a: Department of Geology, Faculty of Sciences, 3995 University of Hormozgan, Bandar Abbas, Iran

b: Department of Sedimentology and Environmental Geology, University of Göttingen, Goldschmidtstraße 3, 37077 Göttingen, Germany

c: Faculty of Geosciences, 3619995161 Shahrood University of Technology, Shahroud, Iran

d: School of Geography, Geology and the Environment, Keele University, Keele, Staffordshire, ST5 5BG, UK e: Department of Geology, Faculty of Sciences, 9177948974 Ferdowsi University of Mashhad, Mashhad, Iran 1

2 Abstract

In Central Iran, the mixed siliciclastic-carbonate Nakhlak Group of Triassic age is commonly seen to have a Cimmerian affinity, although it shows considerable resemblances with the Triassic Aghdarband Group in far northeastern Iran, east of Kopeh-Dagh area, with Eurasian affinity. The Nakhlak Group is composed of the Alam (Late Olenekian-Anisian), Baqoroq (Late Anisian-?Early Ladinian), and Ashin (Ladinian-?Early Carnian) formations consisting mainly of volcanoclastic sandstone and shale and fossiliferous limestone. The Baqoroq Formation contains also metamorphic detritus. Sandstone petrofacies reflect the detrital evolution from active volcanism to growing orogen and again active volcanism. Textural and modal analyses of volcanic lithic fragments from the Alam Formation reflect the eruption style and magma composition of a felsic to intermediate syn-sedimentary arc activity. The

* Corresponding author E-mail address: p.rezaee@hormozgan.ac.ir (P. Rezaee). 
detrital modes of the Baqoroq Formation sediments suggest a recycled orogenic source followed by arc activity in a remnant fore-arc basin. The sandstone samples from the Ashin Formation demonstrate a continuity of felsic to intermediate arc activity. Major and trace element concentrations of the Nakhlak Group clastic samples support sediment supply from first-cycle material and felsic magmatic arc input. The enrichment in LREE, the negative Eu anomalies, and the flat HREE patterns indicate origination from the old upper continental crust and young arc material. The chemical index of alteration (CIA $\sim 51-70$ for sandstone and 64-76 for shale samples) indicates medium degrees of chemical weathering at the source. Petrographical and geochemical evidence together with facies analysis constructed the following depositional conditions for the Nakhlak Group sediments: In the Olenekian, a forearc shallow to deep marine depositional basin developed that later was filled by recycled and arc-related detritus and changed into a continental basin in the Anisian. Ladinian extension let to a deepening of the basin. With respect to the similarities between the Nakhlak and Aghdarband (NE Iran) groups and unusual present-day position of the Nakhlak Group with no stratigraphic connection to the surrounding area, the development of first a fore-arc basin and later change into a back-arc depositional basin in close relation with the Aghdarband basin at the southern Eurasian active margin in the Triassic are here proposed. Understanding the basin development recorded in the Nakhlak Group provides constraints on the closure history of Palaeotethys and of the tectonic evolution of early Mesozoic basins at the southern Eurasian margin before the Cimmerian Orogeny.

Keywords: Triassic; Nakhlak Group; Palaeotethys; Provenance; Central Iran.

\section{Introduction}

The tectonic evolution of Iran with respect to the opening and closing of Palaeotethys and Neotethys oceans and several detaching and attaching events of Hunic terranes and 
47 Cimmerian blocks pertaining to the parental Gondwanan and Eurasian margins is still controversially discussed (e.g., Șengör, 1979; Stampfli, 2000; Stampfli et al., 2002). The Neotethys separated the Cimmerian microcontinent(s) from Gondwana between the latest Palaeozoic and the earliest Tertiary, following a diachronous opening from east to west (Stampfli, 2000). The Iranian Block (Cimmerian Block) collided with the Eurasian Turan Block in Late Triassic time as a result of the Palaeotethys closure; the Eocimmerian Orogeny took place (Stampfli, 2000). The collision between the Iranian Block and the Arabian plate caused the closure of Neotethys and formation of the Zagros Orogen. The timing of this closure, concerning when Arabia started colliding with Eurasia, however, has been highly controversial, ranging from the Late Cretaceous to as late as the Pliocene (for a review see Agard et al., 2011).

A problematic area pertaining to the Palaeotethys evolution is the Central-East Iranian Microcontinent (CEIM) (Fig. 1). It is an allochthonous continental block, bordered by the left lateral Great Kavir-Doruneh fault system in the north, the Nain-Baft fault in the west and southwest, and by the Harirud Fault in the east (Davoudzadeh et al., 1981). The CEIM rotated anticlockwise and is surrounded by Upper Cretaceous to Lower Eocene ophiolites and ophiolitic mélanges, widest in the Sabzevar-Torbat area, considerably narrower at Nain, and locally reduced to an exposed width of only a few hundred meters southwest of the Shirkuh Range (Stöcklin, 1968; Fig. 1). A complex system of intracontinental strike-slip faults (Fig. 1) has caused an intensive north-south dextral shearing of the whole area (more details in Walker and Jackson, 2004). The deformation is accommodated within Central Iran by N-Strending dextral faults, which separate the Yazd, Tabas and Lut blocks. These faults are possibly inherited from Precambrian times (Berberian and Kings, 1981) and were active during the Palaeozoic evolution of the region, as recorded by facies and thickness variations across these structures (Wendt et al., 2005). The Anarak-Khur Block constitutes the 
northwestern part of the CEIM, close to the south of the Great Kavir-Doruneh fault system. This block is characterized by a thick (5000-8000 m) Palaeozoic metamorphic series, detrital sediments and volcanic rocks which contain up to $2500 \mathrm{~m}$ of the marine Triassic sequence of Nakhlak. The Nakhlak Group is unconformably overlain by a well-developed up to $\sim 260 \mathrm{~m}$ thick succession of Upper Cretaceous rocks (Vaziri et al., 2012). The sedimentary Nakhlak Group is a key to understanding the palaeotectonic history of the CEIM in space and time because it is commonly seen to have a Cimmerian affinity (Stöcklin, 1968; Şengör, 1979), although it shows considerable resemblances with the Triassic Aghdarband Group in far northeastern Iran, east of Kopeh-Dagh, with Eurasian affinity (e.g., Davoudzadeh et al., 1981; Ruttner, 1984, 1993).

The composition of terrigenous sedimentary rocks mostly depends on the lithology of the source area(s) and the tectonic setting in which they were deposited (e.g., Dickinson, 1985; McLennan et al., 1993; Ghosh et al., 2012; Armstrong-Altrin et al., 2015). Accordingly, in the present study, we focus on the provenance and tectonic setting of the Nakhlak Group sedimentary succession by using an integrated approach, including modal analysis and whole-rock geochemical data in order to constrain the depositional setting and tectonostratigraphic evolution for this region. Our data provide new information about the sedimentary provenance such as a fore-arc and then a back-arc basin setting for the Nakhlak Group during the Triassic period. Eurasian versus Cimmerian affinities are discussed for the studied sedimentary succession. The tectonic events probably in connection with Eocimmerian collision due to Palaeotethys subduction are discussed as well.

(Figure 1)

\section{Geological setting}


During the Early-Middle Triassic, large parts of Iran were covered by an extensive carbonate platform and deposition has taken place in shallow shelf sea to lagoonal and near-shore tidal flats environments. In eastern Central Iran (Tabas area and Shotori Range) argillaceous carbonate rocks (Sorkh Shale Formation) and thick-bedded dolomite and limestone (Lower to Middle Triassic Shotori Formation) are well developed (Stöcklin et al., 1965; Seyed-Emami, 1971). A thick sequence of siliciclastic, volcano-clastic and basinal sediments of the Nakhlak-Anarak region in Central Iran is completely different among Triassic successions in Iran (Davoudzadeh et al., 1969; Davoudzadeh and Seyed-Emami, 1972) (Fig. 2). Another similar succession occurs in the tectonic window of Aghdarband to the north of the Palaeotethys suture, northeast Iran (east of Mashhad, southeast of Kopeh-Dagh) (SeyedEmami, 1971; Ruttner, 1984; Alavi et al., 1997). Several authors assume that the sedimentary sequences of Nakhlak-Anarak and Aghdarband are closely related at the southern margin of the Turan plate during deposition, and they considered large counterclockwise (CCW) rotation and horizontal movement to the present-day position in Central Iran of the Nakhlak area (e.g., Davoudzadeh et al., 1981; Schmidt and Soffel, 1983; Alavi et al., 1997).

\section{(Figure 2)}

\subsection{Geologic framework of Nakhlak Group}

The Nakhlak Group is exposed to the south of Nakhlak mine (Fig. 2) in the NW-SE-oriented Kuh-e-Qale Bozorg range, approximately $60 \mathrm{~km}$ NNE of Anarak town and $220 \mathrm{~km} \mathrm{NE}$ of Isfahan. The Early-Middle Triassic mixed siliciclastic, volcano-clastic and carbonate sequence of the Nakhlak Group shows almost no lithological similarity with coeval rocks throughout Iran, except for the Aghdarband sequence in the Kopeh-Dagh region (NE Iran). Lithological and biostratigraphical similarities in these two sequences have been considered by several geologists that both were deposited in a similar depositional environment at the 
southern margin of Eurasia during the Triassic period. It has been suggested that the present position of the Nakhlak Group is probably due to the CCW rotation of the Central-East Iranian Microcontinent and its lateral movement to the present position since the Triassic, subsequent to its formation at the Eurasian southern margin (Seyed-Emami, 1971; Davoudzadeh et al., 1981; Krystyn and Tatzreiter, 1991; Soffel and Förster, 1984; Ruttner, 1993; Soffel et al., 1996; Alavi et al., 1997; Saidi et al., 1997; Seyed-Emami, 2003).

Davoudzadeh and Seyed-Emami (1972) subdivided the Nakhlak Group into three formations (from base to top): the Alam Formation (Upper Scythian or Olenekian to Middle Anisian), the Baqoroq Formation (Upper Anisian to Middle Ladinian), and the Ashin Formation (Upper Ladinian to ?Carnian). Rocks immediately underlying the Triassic succession are not well exposed and only small outcrops of mafic and ultramafic rocks can be identified in the southernmost part of the area. These mafic and ultramafic rocks are considered to belong to the Nakhlak-type ophiolitic remnants (serpentinite, boninitic meta-gabbro and basalts, quartz diorite) (Bagheri and Stampfli, 2008; Balini et al., 2009; Zanchi et al., 2009), to which the Triassic succession was thrust upon (Holzer and Ghasemipour, 1973; Sharkovski et al., 1984; Alavi et al., 1997). The Nakhlak exposure is separated from the Anarak mountain chains in the south that is known as Anarak Metamorphic Complex (AMC) by a wide plain. The upper parts of the Nakhlak Group are overlain by Cretaceous limestone above an angular unconformity (Davoudzadeh and Seyed-Emami, 1972; Balini et al., 2009; Vaziri et al., 2012).

\subsection{Stratigraphic ages of Nakhlak Group}

Tozer (1972) suggested that the Alam Formation is Late Olenekian-?Middle Anisian in age, based ammonoid fauna (e.g., Albanites triadicus, Aghdarbandites ismidicus). He introduced Late Ladinian-?Early Carnian ages for the Ashin Formation with respect to few ammonoids (e.g., Megaphyllites sp., Proarcestes sp.) and pelecypods (Daonella lomelli). These ages were 
later confirmed by Vaziri and Fürsich (2007) and Vaziri (2011a and b), based on ammonoid fauna and pelecypods. The continental conglomeratic Baqoroq Formation contains no fossils but based on its stratigraphic position between the Alam and Ashin formations its age is considered to be Upper Anisian to Middle Ladinian (Davoudzadeh and Seyed-Emami, 1972; Balini et al., 2009). The Ashin Formation consists mainly of turbiditic volcano-clastic sandstones and shales with a diversity of well-preserved trace fossils such as Nereites ichnofacies indicating a deep marine origin of the Ashin Formation (Vaziri and Fürsich, 2007). Balini et al. (2009) confirmed the age of the Nakhlak Group and Alam Formation based on the classification of ammonoids as well as conodonts.

\section{Samples and methods}

\subsection{Samples}

The geographic locations of the sampled sections are shown in Figure 2. 450 samples were prepared for petrographic studies and 30 samples for whole-rock geochemical analysis.

\subsection{Methods}

450 thin sections from siltstones, sandstones, fine-grained conglomerates, conglomerate pebbles and carbonate rocks were studied petrographically using a polarizing microscope. Twenty medium- to coarse-grained sandstone samples from the Alam Formation, 20 sandstone samples and two fine-grained conglomerates from the Baqoroq Formation and six sandstone samples from the Ashin Formation were studied (300 points per slide) according to the Gazzi-Dickinson point-counting method (Dickinson, 1970; Ingersoll et al., 1984; Zuffa, 1985). Framework information of the Nakhlak Group sandstones is given in Appendix A. The petrographic Quartz-Feldspar-Lithoclast (QFL) data are provided as Supplementary data (see Appendix A). 
Twenty-one fresh sandstones (nine samples from the Alam, eleven samples from the Baqoroq, and one sample from the Ashin formations) with low content of calcite cement and nine shales (three samples from the Alam, two samples from the Baqoroq, and four samples from the Ashin formations) were selected for whole-rock geochemical analysis. Fresh pieces of each sample devoid of calcite veins were crushed and pulverized in an agate ball-mill. Loss on ignition (LOI) was determined gravimetrically on one $\mathrm{g}$ of sample powders by heating overnight at $1050{ }^{\circ} \mathrm{C}$. For the X-ray fluorescence (XRF) analysis, $1750 \mathrm{mg}$ of finely powdered sample mixed with $3900 \mathrm{mg}$ of lithium tetraborate, lithium metaborate, and LiF were weighted in platinum crucibles and fused for $15 \mathrm{~min}$ at $1100{ }^{\circ} \mathrm{C}$ to prepare glass discs. Major oxides $\left(\mathrm{SiO}_{2}, \mathrm{TiO}_{2}, \mathrm{Al}_{2} \mathrm{O}_{3}, \mathrm{Fe}_{2} \mathrm{O}_{3}, \mathrm{MnO}, \mathrm{MgO}, \mathrm{CaO}, \mathrm{Na}_{2} \mathrm{O}, \mathrm{K}_{2} \mathrm{O}\right.$, and $\left.\mathrm{P}_{2} \mathrm{O}_{5}\right)$ and trace element ( $\mathrm{V}, \mathrm{Cr}, \mathrm{Co}, \mathrm{Ni}, \mathrm{Y}, \mathrm{Zr}, \mathrm{Nb}, \mathrm{Rb}, \mathrm{Sr})$ concentrations were determined on a PANalytical AXIOS Advanced sequential X-ray spectrometer at the University of Göttingen (Department of Geochemistry, Geoscience Center). Relative errors on major and trace elements are $<0.5-$ $2 \%$ and $<2-5 \%$ respectively. All $\mathrm{Fe}$ is reported as $\mathrm{Fe}_{2} \mathrm{O}_{3}$. International geochemical reference samples were used for quality control of data.

Total carbon, organic and inorganic carbon contents of the same 30 samples were measured with a LECO elemental analyzer at the University of Göttingen (Department of Geobiology, Geoscience Center). The data are required for correction of $\mathrm{CaO}$ from carbonate contribution for calculation of the chemical index of alteration (see Section 4.4.).

Selected trace element (Sc, Cu, Zn, Ga, Mo, Cd, Sn, Sb, Cs, Ba, La, Ce, Pr, Nd, Sm, Eu, Gd, Tb, Dy, Ho, Er, Tm, Yb, Lu, Hf, W, Pb, Th, U) concentrations, including rare earth elements (REE), were analyzed in solution by inductively coupled plasma mass spectrometry (ICPMS) using a Perkin Elmer DRC II at the University of Göttingen (Department of Geochemistry, Geoscience Center). Sample powder (100 mg per sample) was dissolved by 
acid digestion with $\mathrm{HF}-\mathrm{HNO}_{3}-\mathrm{HCl}$ prior to analysis, using a PicoTrace ${ }^{\circledR}$ acid sample digestion system. The residuum was solubilized in $10 \mathrm{ml} \mathrm{H}_{2} \mathrm{O}$ and $2 \mathrm{ml} \mathrm{HNO}_{3}$ and $200 \mu \mathrm{l}$ internal standards were added. The solution was diluted to a total volume of $100 \mathrm{ml}$ with ultrapure water. Measurements were calibrated to the standard JA-2 of the Geological Survey of Japan.

The REE data were normalized against C1-chondrite values from Taylor and McLennan (1985). In addition to the chondrite-normalized REE patterns, the Eu anomaly (Eu/Eu* $)$ may serve as a useful discriminant between samples and plate-tectonic settings (e.g., Bhatia, 1985; McLennan, 1989; McLennan et al., 1990), where $\mathrm{Eu}^{*}$ is a theoretical Eu concentration calculated by interpolation between Sm and Gd. The Eu anomaly was quantified according to McLennan (1989): Eu/Eu ${ }^{*}=\mathrm{Eu}_{\mathrm{N}} /\left(\mathrm{Sm}_{\mathrm{N}} \times \mathrm{Gd}_{\mathrm{N}}\right)^{0.5}$, where the subscript $\mathrm{N}$ denotes chondritenormalized values. Values of $\mathrm{Eu} / \mathrm{Eu}^{*}>1$ are considered to be positive, whereas values $<1$ are considered to be negative (McLennan et al., 1990).

The Chemical Index of Alteration (CIA) was calculated using molecular proportions as follows (Nesbitt and Young, 1982): CIA $=100 \times \mathrm{Al}_{2} \mathrm{O}_{3} /\left(\mathrm{Al}_{2} \mathrm{O}_{3}+\mathrm{CaO}^{*}+\mathrm{Na}_{2} \mathrm{O}+\mathrm{K}_{2} \mathrm{O}\right)$, where $\mathrm{CaO}^{*}$ is the amount of $\mathrm{CaO}$ incorporated in the silicate fraction of the rock and quantified using a formula presented by Fedo et al. (1995): $\mathrm{CaO}^{*}=$ mol $\mathrm{CaO}-\mathrm{mol}$ $\mathrm{CO}_{2}($ calcite $)-(0.5 \times \mathrm{mol} \mathrm{CO} 2)($ dolomite $)-\left[(10 / 3) \times \mathrm{mol} \mathrm{P}_{2} \mathrm{O}_{5}\right]($ apatite $)$

The index of compositional variability (ICV), which is useful to assessing the compositional maturity of fine-grained siliciclastics, was quantified as follows (Cox and Lowe, 1995): ICV $=\left(\mathrm{Fe}_{2} \mathrm{O}_{3}+\mathrm{K}_{2} \mathrm{O}+\mathrm{Na}_{2} \mathrm{O}+\mathrm{CaO}+\mathrm{MgO}+\mathrm{TiO}_{2}\right) / \mathrm{Al}_{2} \mathrm{O}_{3}$; in this equation, $\mathrm{CaO}$ includes also the Ca sources related to detrital carbonate and phosphate (e.g., Perri et al., 2012).

A new multi-element discrimination diagram proposed by Verma and Armstrong-Altrin (2013) was used for tectonic discrimination. This diagram, partitioned into three main 
214 categories (arc, collision and rift settings) is based on two discriminant functions using ten major oxides $\left(\mathrm{SiO}_{2}, \mathrm{TiO}_{2}, \mathrm{Al}_{2} \mathrm{O}_{3}, \mathrm{Fe}_{2} \mathrm{O}_{3}, \mathrm{MnO}, \mathrm{MgO}, \mathrm{CaO}, \mathrm{Na}_{2} \mathrm{O}, \mathrm{K}_{2} \mathrm{O}\right.$, and $\left.\mathrm{P}_{2} \mathrm{O}_{5}\right)$.

\section{Results}

\subsection{Measured sections}

The Nakhlak Group at the base tectonically overlies (shear zone) massive metamorphic rocks that are strongly silicified and altered. The Alam Formation starts at the bottom with alternating volcano-clastic sandstone and limestone beds, massive oolitic limestone, fossiliferous thin-bedded limestone, and continues to green and purple volcano-clastic sandstone and shale sequences with some ammonoid-bearing shale bed intervals, intraformational conglomerates, thick wavy pseudo-nodular grey colored fossiliferous limestone, and finally at the top light green colored foliated shale beds inter-bedded with thin beds of light brown limestone and sandstone.

The Baqoroq Formation overlies the Alam Formation atop an erosional unconformity. It starts with a medium bedded conglomerate bed that is composed of oolitic limestone pebbles that most likely originated from the base of the Alam Formation. The majority of the Baqoroq Formation is made up of very thick bedded to massive red colored conglomerate beds intercalated with sandstone and shale beds. Limestone lithoclasts, especially oolitic grainstones, are observed throughout the formation. The first $200 \mathrm{~m}$ of the succession are dominated by volcanic clasts. Subsequently, metamorphic lithoclasts become more dominant than volcanic. Quartzite and polycrystalline quartz lithoclasts are common throughout the whole succession.

The Ashin Formation unconformably lies atop the Baqoroq Formation. The Ashin Formation is composed of thin-bedded volcanic sandstone and shale beds, intercalated with ammonoid- 
bearing shale beds and fossiliferous limestone with two thin limestone beds rich in crinoid fragments near the top. The formation is characterized by a dominance of green-colored shale, frequency of trace fossils, huge septarian nodules, and groove marks. The top of the formation is truncated by a thrust fault.

\subsection{Petrography and modal analysis}

Framework compositions of the studied sandstones and conglomerates can be subdivided into following petrofacies according to Weltje (2006; Fig. 3); which are lithoquartzose, feldspatholithic, lithofeldspathic and quartzofeldspathic in the Alam Formation, quartzolithic, lithoquartzose, and feldspathoquartzose in the Baqoroq Formation, and lithofeldspathic, quartzofeldspathic, and feldspathoquartzose in the Ashin Formation. The full set of petrographic data is given in the accompanying Supplementary data (see Appendix A).

\subsubsection{Alam Formation}

Most of the sandstone samples from the Alam Formation contain dominantly volcanic detritus represented by lithic fragments (Fig. 4a-c) and single phenocrysts (Fig. 4d). Quartz grains showing straight extinction and embayment features are common. The volcaniclastic interstitial component is mainly pseudo matrix formed by compaction of loose volcanic detritus. Vitric lithic grains are considerable in the Alam Formation sandstones. Some samples are composed primarily of volcanic monoliths.

Lithoquartzose sandstones (average $\mathrm{Q}_{67}-\mathrm{F}_{6}-\mathrm{L}_{27}$ ) are mainly composed of monocrystalline volcanic quartz and volcanic lithic fragments. Feldspatholithic sandstones (average $\mathrm{Q}_{12}-\mathrm{F}_{29}-$ $\left.\mathrm{L}_{59}\right)$ are mostly composed of volcaniclastic detritus. Quartz and feldspar phenocrysts are also present. K-feldspars are mostly sanidine. Lithofeldspathic sandstones (average $\mathrm{Q}_{6}-\mathrm{F}_{73}-\mathrm{L}_{21}$ ) are chiefly composed of K-feldspar phenocrysts (mostly sanidine). Quartzofeldspathic 
sandstones (average $\mathrm{Q}_{34}-\mathrm{F}_{50}-\mathrm{L}_{19}$ ) are composed of feldspars, quartz phenocrysts and volcanic lithic fragments. Volcanic clasts from the Alam Formation are mainly show microlitic and vitric homogeneous textures, and minor lathwork and felsitic textures which are variable throughout the formation with no distinct stratigraphic trends. (Fig. 4a-c). A few of the large microlitic clasts show porous (amygdaloidal) clasts that are filled with secondary chlorite (Fig. 4a) indicative of a gaseous phase present during rock formation. Heavy minerals such as zircon, chrome spinel and opaque minerals occur.

\subsubsection{Baqoroq Formation}

Sandstones and conglomerates of the Baqoroq Formation are characterized by: 1) the presence of recycled orogenic detritus; 2) the presence of volcanic detritus; 3) the overall increase in the proportion of metamorphic detritus and decrease in volcanic detritus from base to top; 4) common polycrystalline quartz grains; 5) mature texture.

Quartzolithic sandstones (average $\mathrm{Q}_{37}-\mathrm{F}_{17}-\mathrm{L}_{46}$ ) are mainly composed of polycrystalline quartz and volcanic lithic fragments. This petrofacies represents the basal portions of the formation. Lithoquartzose sandstones (average $\mathrm{Q}_{49}-\mathrm{F}_{17}-\mathrm{L}_{34}$ ) are composed of both volcanic and metamorphic detritus. This petrofacies is spread out across the formation although more commonly found in the intermediate sections. Feldspathoquartzose sandstones (average $\mathrm{Q}_{54}-$ $\left.\mathrm{F}_{27}-\mathrm{L}_{19}\right)$ are composed of polycrystalline quartz grains and metamorphic detritus, which represent the upper parts of the formation. Metamorphic clasts are metapsammite/metafelsite grains rank 2 and 3, according to the Garzanti and Vezzoli (2003) classification, composed of quartz-sericite and quartz-mica (muscovite) lithic fragments (Fig. 4e-f). Volcanic clasts are mainly vitric homogeneous, microlitic, minor felsitic and lathwork (Fig. 4g). The volcanic particles are generally fresh and larger than other terrigenous clasts. The muscovite modal content increases from base to top. Heavy minerals are the same as in the Alam Formation. 


\subsubsection{Ashin Formation}

The sandstone samples from the Ashin Formation contain mainly K-feldspar phenocrysts and quartz grains. These sandstones are matrix supported and strongly affected by diagenetic iron oxide, dendritic manganese, and calcium replacement.

Lithofeldspathic sandstones (average $\mathrm{Q}_{17}-\mathrm{F}_{64}-\mathrm{L}_{19}$ ) are chiefly composed of euhedral Kfeldspar grains (sanidine) oriented in the matrix along with volcanic lithic, quartz grains and some coeval crinoid stem debris. Quartzofeldspathic sandstones (average $\mathrm{Q}_{24}-\mathrm{F}_{69}-\mathrm{L}_{7}$ ) are also composed of euhedral K-feldspar (sanidine) grains and single crystalline volcanic quartz grains. Feldspathoquartzose sandstones (average $\mathrm{Q}_{51}-\mathrm{F}_{27}-\mathrm{L}_{22}$ ) include more volcanic quartz grains than the other two petrofacies. Volcanic fragments are mainly microlitic and vitric homogeneous as well as comprise some lathwork texture. Heavy minerals are the same as in the two other formations.

(Figure 3)

(Figure 4)

\subsection{Whole-rock geochemistry}

\subsubsection{Alam Formation}

The rocks display moderate to high major element concentrations compared with average upper continental crust composition (Rudnick and Gao, 2003); the $\mathrm{SiO}_{2}$ average content is 62.5-89.8 wt.\%, the $\mathrm{Al}_{2} \mathrm{O}_{3}$ is $11.6-19.6$ wt.\% and sandstone sample AN12' with 5.7 wt.\%, the $\mathrm{TiO}_{2}$ average content is $0.22-0.99$ wt. $\%$, the $\mathrm{Fe}_{2} \mathrm{O}_{3}$ average content is $2-7$ wt. $\%$ and $\mathrm{CaO}$ has a variable total content $(0.6-9.8$ wt.\%) in sandstone and high total $\mathrm{CaO}$ content $(5.2-40.7$ wt.\%) in shale samples (see Table 1). $\mathrm{CaO}$ and LOI show a positive linear correlation for most sandstone and shale samples from the Nakhlak Group (Supplementary Fig. S2). The 
samples have medium to low trace element concentrations (Appendix A) in Ni (11-28 ppm), $\mathrm{Cr}(7-65 \mathrm{ppm}), \mathrm{Ba}(76-510 \mathrm{ppm})$, and $\mathrm{Zr}(59-168 \mathrm{ppm})$, low to high concentrations in $\mathrm{V}$ (19-112 ppm), and variable Sr concentrations (104-3080 ppm).

Most trace elements are enriched, with characteristic positive $\mathrm{Sr}$ anomalies and depletion in $\mathrm{Ba}, \mathrm{Zr}, \mathrm{V}$ and $\mathrm{Cr}$, and variable negative and positive $\mathrm{K}$ anomalies (Fig. 5a-c). Chondritenormalized REE patterns (Taylor and McLennan, 1985; Fig. 5d-f) show light rare earth element (LREE) enrichment $\left(\mathrm{La}_{\mathrm{N}} / \mathrm{Yb}_{\mathrm{N}} \sim 4.1\right.$ and 7.3$)$ and flat heavy rare earth element (HREE) profiles $\left(\mathrm{Gd}_{\mathrm{N}} / \mathrm{Yb}_{\mathrm{N}} \sim 1.1\right.$ and 1.6$)$ with a negative $\mathrm{Eu}$ anomaly $\left(\mathrm{Eu} / \mathrm{Eu}^{*} \sim 0.6-0.8\right)$ in seven samples, a positive $\mathrm{Eu}$ anomaly $\left(\mathrm{Eu} / \mathrm{Eu}^{*} \sim 1.0-1.5\right)$ in three samples and a weak Eu anomaly $\left(\mathrm{Eu} / \mathrm{Eu}^{*} \sim 0.9\right)$ in two samples. REE data are given in the Supplementary data (see Appendix A).

\subsubsection{Baqoroq Formation}

The rocks display high $\mathrm{SiO}_{2}\left(72.5-82.7\right.$ wt.\%), low to moderate $\mathrm{Al}_{2} \mathrm{O}_{3}$ (9.7-15.2 wt.\%), low to high $\mathrm{TiO}_{2}\left(0.38-0.78\right.$ wt.\%), low to moderate $\mathrm{Fe}_{2} \mathrm{O}_{3}(2.3-5.8$ wt.\%) and variable total $\mathrm{CaO}$ content (0.7-7.2 wt.\%) in sandstone and high total $\mathrm{CaO}$ content $(9.2-31$ wt.\%) in shale samples (Table 1). The samples have medium to low trace element concentrations (Appendix A) in $\mathrm{Ni}(10-26 \mathrm{ppm}), \mathrm{Cr}(11-52 \mathrm{ppm}), \mathrm{Ba}(74-497 \mathrm{ppm}), \mathrm{V}(31-62 \mathrm{ppm})$, and variable medium to high concentrations in $\mathrm{Zr}(92-212 \mathrm{ppm})$ and $\mathrm{Sr}(61-850 \mathrm{ppm})$.

The elements exhibit a similar pattern as for the Alam Formation samples. The Baqoroq Formation shows enrichment in $\mathrm{Y}$ and $\mathrm{Sc}$, and characteristic enrichment in $\mathrm{Sr}$ in seven samples and depletion in five samples, and also depletion in $\mathrm{Ba}, \mathrm{V}$ and $\mathrm{Cr}$, characteristic negative anomalies in $\mathrm{K}$ in two arenites and slightly positive anomalies in two shale samples and one feldspathic volcanic arenite (Fig. 5a-c). Chondrite-normalized REE patterns (Taylor and McLennan, 1985; Fig. 5d-f) show a light rare earth element (LREE) enrichment 
$331\left(\mathrm{La}_{\mathrm{N}} / \mathrm{Yb}_{\mathrm{N}} \sim 3.1\right.$ and 9.7) and flat heavy rare earth element (HREE) profiles $\left(\mathrm{Gd}_{\mathrm{N}} / \mathrm{Yb}_{\mathrm{N}} \sim 0.8\right.$ and 1.6) with a negative $\mathrm{Eu}$ anomaly $\left(\mathrm{Eu} / \mathrm{Eu}^{*} \sim 0.6-0.8\right)$ in almost all samples and a nearly flat $\mathrm{Eu} / \mathrm{Eu}^{*}$ pattern in sample $\mathrm{B} 37\left(\mathrm{Eu} / \mathrm{Eu}^{*} \sim 0.9\right)$. REE data are given in the Supplementary data (see Appendix A).

\subsubsection{Ashin Formation}

The rocks display moderate $\mathrm{SiO}_{2}\left(64-75.2\right.$ wt.\%), $\mathrm{Al}_{2} \mathrm{O}_{3}$ (12.3-19.3 wt.\%), $\mathrm{TiO}_{2}(0.53-0.71$ wt.\%), $\mathrm{Fe}_{2} \mathrm{O}_{3}(5.1-8.3$ wt.\%) and high total $\mathrm{CaO}$ content (11 wt.\%) in sandstone and high total $\mathrm{CaO}$ content (5-8.9 wt.\%) in shale samples (Table 1). Trace elements in the Ashin Formation have low to high concentrations of Ni (26-62 ppm) and V (57-123 ppm), and low Cr (36-80 ppm), Ba (109-456 ppm), Zr (135-187 ppm), and Sr concentrations (132-284), which is different from the Alam and Baqoroq formations (Appendix A).

The elements exhibit fairly similar patterns compared to samples from the two other formations; most of the trace elements show slightly enrichment or depletion in $\mathrm{Ba}, \mathrm{Sr}$ and $\mathrm{Cr}$, and variable positive and negative anomalies in $\mathrm{K}$ (Fig. 5a-c). Chondrite-normalized REE patterns (Taylor and McLennan, 1985; Fig. 5d-f) show a light rare earth element (LREE) enrichment (slightly more than for the two other formations) $\left(\mathrm{La}_{\mathrm{N}} / \mathrm{Yb}_{\mathrm{N}} \sim 6.4\right.$ and 7.1 ) and nearly flat heavy rare earth element (HREE) profiles $\left(\mathrm{Gd}_{N} / \mathrm{Yb}_{\mathrm{N}} \sim 1.3\right.$ and 2.4) with a negative $\mathrm{Eu}$ anomaly $\left(\mathrm{Eu} / \mathrm{Eu}^{*} \sim 0.6\right)$. REE data are given in the Supplementary data (see Appendix A).

(Table 1)

(Figure 5)

\subsection{Palaeo-weathering and sediment recycling}


The CIA mean values of the analyzed sandstones are 58.59 for the Alam Formation, 62.98 for the Baqoroq Formation, and 61.78 for the Ashin Formation (see Appendix A). For the shales calculated CIA mean values are slightly higher than for the sandstones ( 71.27 for the Alam, 73.07 for the Baqoroq, and 69.35 for the Ashin formations). They are close to the postArchean Australian shale (PAAS) value (McLennan, 1989). For most of the studied samples, the ICV values are greater than one (average ICV $=1.3$ for the Alam Formation; 1.1 for the Baqoroq Formation; 1.4 for the Ashin Formation). (3)

(1)

All samples from the Alam Formation show Th/U lower than 4.0 (1.8 to 3.9). Three samples have $\mathrm{Th} / \mathrm{U}$ values of $1.81,2.74$, and 2.84 (Fig. 7a), which are the same samples with enrichment in Eu (AN12', AN63, and AN159; Fig. 5d). Five sandstone and two shale samples from the Baqoroq Formation show Th/U values lower than 4.0 (2.9 to 3.7). One of them (sample B37, $\mathrm{Th} / \mathrm{U}=2.98$ ) plots mostly inside the depleted mantle sources field (Fig. 7a), and shows a flat Eu pattern (Fig. 5e). The other six samples from the Baqoroq Formation plot in the upper crust field with $\mathrm{Th} / \mathrm{U}$ values of 4.0 to 5.2 (Fig. 7a). Samples from the Ashin Formation show $\mathrm{Th} / \mathrm{U}$ values of 3.4 to 4.0 (Fig. 7a).

$\mathrm{Th} / \mathrm{Sc}$ values of the studied samples range from 0.11 to 1.08 for the Alam Formation, from 0.31 to 0.93 for the Baqoroq Formation, and from 0.50 to 0.77 for the Ashin Formation. $\mathrm{Zr} / \mathrm{Sc}$ values range from 4.30 to 21.43 for the Alam Formation, from 10.67 to 31.11 for the Baqoroq Formation, and from 7.54 to 19.86 for the Ashin Formation.

\section{(Figure 7)}

\subsection{Provenance}


The $\mathrm{TiO}_{2} / \mathrm{Zr}$ values of the Nakhlak Group sediments are 41.5 on average. Three sandstone samples of the Alam Formation have higher $\mathrm{TiO}_{2} / \mathrm{Zr}$ values $(95.5$ for $\mathrm{AN} 112,73.4$ for AN133, 117.8 for AN159).

Despite the presence of detrital chrome spinel (Hashemi Azizi et al., 2018) the sediments of the Nakhlak Group seem to have not received (ultra)mafic detritus (Fig. 8b). The average values of $\mathrm{Cr} / \mathrm{Ba}$ and $\mathrm{Ni} / \mathrm{Ba}$ are 0.15 and 0.1 , respectively. The average $\mathrm{Cr} / \mathrm{Ni}$ ratio is $\sim 1.5$ throughout the Nakhlak Group, which is close to the $\mathrm{Cr} / \mathrm{Ni}$ ratio of ultramafic rocks $(\sim 1.6)$. Two samples from Alam (AN112) and Baqoroq (B37) formations show high $\mathrm{Cr} / \mathrm{Ni}$ ratios of 3.4 and 5.2, respectively, suggesting significant sedimentary fractionation (Garver et al., 1996). Carbonate cementation and replacement of feldspars by calcite have been observed in Nakhlak Group sandstones (see Section 4.2.). All samples show high concentrations of $\mathrm{SiO}_{2}$ (>61\%), similar to dacite and rhyolite (Fig. 8c).

(Figure 8)

(Figure 9)

\section{Discussion}

\subsection{Alam Formation}

The sedimentary record of the Upper Olenekian-Anisian Alam Formation is a key to understanding the evolution of a fore-arc basin at the southern active margin of Eurasia pertaining to the closure of Palaeotethys. The oolitic massive limestone close to the base of the succession demonstrates shallow shelf depositional conditions corresponding to a shallow fore-arc basin. Ammonoid- and conodont-bearing limestone intervals intercalated with volcano-clastic sandstone and shale beds (Balini et al., 2009). These types of sedimentary 
succession are related to deposition in an active basin with numerous volcanic eruptions and quench fragmentation. By turning the depositional condition into a quiescent situation it became favorable for carbonate to precipitate in an open marine shelf environment.

As mentioned earlier, sandstones from the Alam Formation contain volcanic lithic fragments showing various textures. In an active arc setting different types of volcanic activity show different textures in volcano-clastic rocks, thus pure volcanolithic sandstones testify direct relations with the types of volcanic activity within the arc (e.g., Critelli et al., 2002; Marsaglia et al., 2016). The microlitic texture observed in the Alam Formation (Fig. 4a-b) is typical of andesites (Critelli et al., 2002). According to Critelli and Ingersoll (1995) and Critelli et al. (2002), the lack of lathwork volcanic lithic fragments in the Alam Formation sandstones is characteristic of the deficiency of basaltic and basaltic andesite lavas and pyroclasts. The high quartz content in these sandstones may point to a proximal felsic volcanic facies that could be attributed to a "quasi-continental" more highly evolved magmatic-arc source (Critelli et al., 2002). Another possibility for this can be a higher maturity of the sedimentary rock which is unlikely in the case of the Nakhlak Group.

Critelli et al. (2002) declare that syneruptive sandstones generally contain more vitric lithic grains as in the Alam Formation sandstones. Samples composed primarily of volcanic monoliths are affiliated with instantaneous eruptions that considerably dilute non-volcanic contributions.

\subsection{Baqoroq Formation}

Massive conglomerate beds with granule- to boulder-sized grains show high-energy depositional conditions in a continental setting. Considering the immature textures of the Baqoroq Formation siliciclastics and the absence of rounded detritus, a proximal position to the source rocks is inferred. The conglomerates are composed of volcanic, metamorphic, 
quartzite and limestone fragments (Hashemi Azizi and Rezaee, 2014). As mentioned, volcanic particles are fresh and large which suggest a derivation from Triassic felsic to intermediate volcanism. Our petrographic analyses confirm felsic magmatic and sedimentary rocks and continuous activation of surrounding arcs. Metamorphic rocks, with polycrystalline quartz grains derived from an uplifted basement, also supplied detritus to the basin. The presence of metamorphic detritus in the Baqoroq Formation also implies the presence of tectonic uplift in the source area, which allowed exhumation of metamorphic basement in the adjacent terrain. Alternatively, as the geochemical composition of the Baqoroq Formation is similar to the Alam Formation, a similar source rock composition and tectonic setting are suggested. Rapidly changed depositional environment from marine to terrestrial during the Anisian supports a local tectonic event at the southern margin of Eurasia during the Middle Triassic, probably in connection with an Eocimmerian collisional event due to Palaeotethys subduction (Şengör, 1979; Stampfli, 2000; Muttoni et al., 2009a, b). Thereafter, we suggest that an open marine sedimentary basin was replaced by a terrestrial deposition system. The petrographic composition of the Baqoroq Formation sandstones resembles that of remnant ocean basins (ROB) around the world such as Makran Group in southwest Pakistan (Critelli et al., 1990) and Mediterranean-type ROB (Critelli, 1993; Critelli et al., 2017).

\subsection{Ashin Formation}

The Ashin Formation illustrates an open marine sedimentary basin evidenced by turbidites (probably distal) and the Nereites ichnofacies (Vaziri and Fürsich, 2007). The shift from a continental sedimentary basin to an open marine basin would be due to a rifting event probably triggered by Palaeotethys subduction beneath Eurasia. An alternative explanation could be basin subsidence. Petrographic evidence shows a dominant volcanic input. The presence of volcanic quartz is consistent with the presence of silicic pyroclastic volcanic rocks in oceanic arcs undergoing extension/rifting, which is known from both modern (e.g., 
Izu arc) and ancient (Alistos arc) arcs (Busby et al., 2006; Marsaglia et al., 2016). Besides, colorless felsic glass is a major component in volcanic sediment produced during arc rifting (Critelli et al., 2002 and references therein).

\subsection{Nakhlak Group geochemistry}

$\mathrm{SiO}_{2}$ content and variable trace element concentrations, especially very low $\mathrm{Cr}, \mathrm{V}$ and $\mathrm{Th}$ contents in the Nakhlak Group samples, indicate more first-cycle material and felsic magmatic arc input. The positive linear correlation between total $\mathrm{CaO}$ and $\mathrm{LOI}$ indicates the presence of carbonate-bearing minerals such as calcite in siliciclastic samples from the Alam, Baqoroq, and Ashin formations. High Sr concentrations ( $\sim 634 \mathrm{ppm}$ on average) in most of the samples are probably due to high feldspar content as well as calcium carbonate cementation. Salminen et al. (2005) quantified the average Sr concentration in quartzofeldspathic rocks to about $600 \mathrm{ppm}$, and high $\mathrm{Sr}$ concentration ( 2071 ppm) occurs in calcium carbonate cemented samples. The REE concentrations indicate origination from old upper continental crust and young arc material (McLennan et al., 1993). Those samples showing positive Eu anomalies could have been sourced from fresh mantle-derived material. Specific ratios (e.g., $\mathrm{Th} / \mathrm{Sc}, \mathrm{Th} / \mathrm{U}, \mathrm{Eu} / \mathrm{Eu}^{*}$ ) suggest derivation from young (undifferentiated and differentiated) arc material.

Chemical weathering causes exposed rocks to be disaggregated or dissolved through chemical processes (Nesbitt, 2003). Quantitative measures, such as the chemical index of alteration (CIA; Nesbitt and Young, 1982) are useful to evaluate the degree of chemical palaeo-weathering. This index indicates a medium degree of chemical weathering at the source area of the Nakhlak Group according to Fedo et al. (1995). Another approach to assessing the number of weathered minerals in fine-grained siliciclastics is to use the index of compositional variability (ICV). The ICV values for the Nakhlak Group samples means 
relatively unweathered detrital minerals occurred in first-cycle deposits according to Cox and Lowe (1995). CIA values plotted against ICV (Potter et al., 2005) show fresh granite to fresh andesite as a source rock for the sandstones and slightly weathered basalts as a source rock for the shales (Fig. 6a).

CIA has a linear trend for Nakhlak Group sandstones and shales from ca. 50 to ca. 70 (Fig. 6b). According to Roser et al. (2002), CIA ratios and A-CN-K trends can also be influenced by tectonism in stable margins and active tectonic setting. In the case of our samples, the linear trend of Nakhlak Group sandstones and shales from fresh andesite and fresh dacite to PAAS imply uplift and emplacement of fresh volcanic rocks in active tectonic settings such as fore-arc and back-arc basins.

$\mathrm{Th} / \mathrm{U}$ elemental ratios (McLennan et al., 1993) evaluate that the Nakhlak samples were derived from source rocks with a low degree of weathering or material with insignificant recycling particularly in the Alam and Ashin formations. In the Baqoroq Formation the data suggest a mixture source rocks ranging from unweathered magmatic to metamorphic regions, as confirmed by petrography.

One effect of sedimentary sorting results in an enrichment of heavy minerals (e.g., zircon, monazite, and magnetite) in sand and sandstone (Pettijohn et al., 1987), and tends to strongly enrich sands in the trace elements associated with those minerals (McLennan et al., 1993; McLennan, 2001). Thus $\mathrm{Th} / \mathrm{Sc}$ plotted against $\mathrm{Zr} / \mathrm{Sc}$ values can detect zircon enrichment during sediment recycling; although during most igneous differentiation processes, both Th and $\mathrm{Zr}$ become more enriched relative to Sc and considering that both $\mathrm{Th}$ and $\mathrm{Zr}$ are enriched in heavy minerals (e.g., monazite and zircon) zircon is typically far more abundant than monazite (McLennan et al., 2003). $\mathrm{Zr} / \mathrm{Sc}$ and $\mathrm{Th} / \mathrm{Sc}$ elemental ratios suggest some compositional variation in the source area of the Nakhlak Group but do not indicate strong 
zircon enrichment (Fig. $7 \mathrm{~b}$ ). $\mathrm{TiO}_{2}$ and $\mathrm{Zr}$ are rather immobile during weathering and may be useful indices for detecting the source rock composition. $\mathrm{TiO}_{2} / \mathrm{Zr}$ values can distinguish between mafic and felsic rocks (Hayashi et al., 1997). The $\mathrm{TiO}_{2} / \mathrm{Zr}$ values of the Nakhlak Group sediments point mostly toward felsic igneous source rocks for sandstone and shale samples. High $\mathrm{TiO}_{2} / \mathrm{Zr}$ values from the Alam Formation suggesting intermediate igneous source rocks.

The influence of a mafic-ultramafic source can be evaluated using $\mathrm{Ni} / \mathrm{Co}, \mathrm{Cr} / \mathrm{V}, \mathrm{Cr} / \mathrm{Ni}$ and Y/Ni (McLennan et al., 1993; Meinhold et al., 2007; Jafarzadeh et al., 2014; ArmstrongAltrin et al., 2015). For example, $\mathrm{Cr} / \mathrm{V}$ vs. Y/Ni can be used to illustrate the importance of mafic-ultramafic (ophiolitic) source rocks (McLennan et al., 1993). $\mathrm{Cr} / \mathrm{V}$ is an index of $\mathrm{Cr}$ over the other ferromagnesian trace elements, whereas $\mathrm{Y} / \mathrm{Ni}$ shows the general level of ferromagnesian trace elements (Ni) compared to $\mathrm{Y}$ which is representative for HREE (McLennan et al., 1993). Mafic-ultramafic sources tend to have high ferromagnesian abundances and show low Y/Ni. According to Garver et al. (1996), Cr and Ni concentrations are strong indicators for the involvement of (ultra)mafic rocks. Ba concentrations can be used to monitor the contribution of felsic crystalline rocks (von Eynatten, 2003). The values of $\mathrm{Cr} / \mathrm{Ba}$ and $\mathrm{Ni} / \mathrm{Ba}$ throughout the Nakhlak Group suggest a common source of $\mathrm{Cr}$ and $\mathrm{Ni}$. The average $\mathrm{Cr} / \mathrm{Ni}$ ratio throughout the Nakhlak Group, which is close to the $\mathrm{Cr} / \mathrm{Ni}$ ratio of ultramafic rocks, is suggesting only minor geochemical partitioning (Garver et al., 1996). Detrital chrome spinel is present in Nakhlak Group sandstone (Hashemi Azizi et al., 2018) but according to some geochemical proxies (Fig. 8b) the sediments of the Nakhlak Group seem to have not received (ultra)mafic detritus. Other provenance studies (e.g., von Eynatten, 2003) attribute this discrepancy to carbonate dilution effects, either from detrital carbonate fragments or diagenetic carbonate cement. 
The Nakhlak group samples show high concentrations of $\mathrm{SiO}_{2}$, similar to dacite and rhyolite, which likely represent the source rock composition for all samples. One sample that plots in the trachy-andesite category is exceptional. A high maturity might also be the reason for high $\mathrm{SiO}_{2}$ content. However, this possibility can be rule out here regarding the high volcanoclastic content and immature texture of the sandstones.

\subsection{Tectonic setting}

Detrital mineralogy and chemical compositions of clastic sedimentary rocks may indicate the tectonic setting of the source areas (e.g., Dickinson, 1985; McLennan et al., 1993; Armstrong-Altrin et al., 2015). The QFL ternary diagrams of Weltje (2006) are more promising with less error compared to the equivalent diagrams proposed by Dickinson (1985) and Dickinson and Suczek (1979). Samples from all three formations illustrate magmatic arc source in addition to a recycled orogen for the Baqoroq Formation. However, the QmPK diagram discriminates continental block as source area which cannot be acceptable for fresh volcano-clastic sandstones. The reason for such discrepancy can be addressed by the high Kfeldspar content of the Nakhlak samples come from the parent rocks with rhyolitic and trachytic nature.

Major oxide composition of the most Nakhlak Group sandstones and shales illustrating arc setting (Fig. 10) (Verma and Armstrong-Altrin, 2013); one sandstone sample from the Baqoroq Formation has a composition in accordance with rift setting (Fig. 10). There is a low-silica sandstone sample from the Alam Formation which has a composition in agreement with arc setting (Fig. 10).

The plate tectonic setting controls the chemical composition of siliciclastic rocks (Bhatia, 1983) and different tectonic settings, thus, have different geochemistry (Roser and Korsch, 1988). According to some of the major oxides, almost all samples from the Nakhlak Group 
544 show a composition in agreement with active margin tectonic setting. One shale sample from the Ashin Formation (AS116) has exceptionally a composition conformable with the passive margin setting but it is close to the border of active margin (Fig. 11a). Two sandstone samples of the Alam Formation (AN63 and AN159) have the compositions similar to the oceanic island arc (Fig. 11a).

The diagram based on major elements shows active margin tectonic setting for the Nakhlak Group samples (Fig. 11b). Only two sandstone samples from the Alam Formation have the compositions in accordance with the passive margin, but those are located close to the activepassive margin boundary. Figure 11c shows an active margin tectonic setting for the Nakhlak Group samples based on major and trace elements, except for one sandstone sample from the Alam Formation, which has a composition of the passive margin but it is located on the active-passive margin boundary.

According to Bhatia (1985) and Bhatia and Crook (1986), several REE-related parameters (e.g., $\mathrm{La}_{\mathrm{N}} / \mathrm{Yb}_{\mathrm{N}}, \mathrm{Eu} / \mathrm{Eu}^{*}, \mathrm{La} / \mathrm{Y}$; Appendix A) are useful to distinguish the tectonic settings of sedimentary basins. The average Alam and Baqoroq formations samples display a mixture setting of CIA, OIA, and ACM. The Ashin Formation samples also mainly show a CIA setting and some ratios show ACM setting.

(Figure 10)

(Figure 11)

(Figure 12)

\subsection{Possible connections between Nakhlak and Kopeh-Dagh regions}

During the Late Palaeozoic, the Kopeh-Dagh area, belonging to the Hun Superterrane, had been accreted to the Turan plate (Baud and Stampfli, 1989). Northward subduction and the 
slab roll-back of the subducted part of the Palaeotethys triggered the opening of back-arc oceans along the active Eurasian margin from Austria to the Pamirs after Late Permian times. The size and history of these Permian-Triassic marginal basins differ from area to area (Stampfli, 2000; Stampfli and Borel, 2002). During the Triassic, north of the magmatic arc and in a back-arc setting, a deep subsiding volcano-sedimentary marine belt is recognized stretching from the South Caucasus through the Kopeh-Dagh to the North Pamir (Baud and Stampfli, 1989). A deformed segment of this back-arc basin crops out in the erosional window of Aghdarband in the eastern Kopeh-Dagh range, northeast Iran (Baud and Stampfli, 1989; Stampfli, 2000). Lithologically, the Triassic Aghdarband Group, 1.2-1.5 km thick, is subdivided into three formations (Sefid Kuh, Sina, and Miankuhi formations) and shows a complete sedimentary cycle of shallow water carbonate rocks (Early Triassic) through deep water andesitic to trachytic volcaniclastics (Middle to early Late Triassic) to continental siltstones and sandstones with coal seams (Late Triassic) (Baud and Stampfli, 1989, Alavi et al., 1997).

Our new data from the Nakhlak Group suggest similar depositional environments and tectonic settings. The Nakhlak Group was probably deposited in close proximity to the Aghdarband basin. For the Early Triassic, marine depositional conditions in a fore-arc setting are confirmed by the siliciclastic and carbonate succession of the Alam Formation from arc activity. The basin was later filled in the Anisian with sediment and the depositional conditions changed to a continental setting depositing the Baqoroq Formation. The clastic input of the Baqoroq Formation highlights the tectonic uplift in the surrounding regions. Uplift started during the deposition of member G from the Alam Formation (Balini et al., 2009) and continued into the Baqoroq Formation. This coeval tectonic activity, which caused an influx of quartz grains throughout the Baqoroq Formation (Qt in Fig. 12) and metamorphic rock fragments in the upper part of the formation (MRF in Fig. 12), was likely related to rift 

shoulder uplift. This extensional regime within the former fore-arc environment led to the formation of a small, short-lived oceanic basin in which the Ashin Formation was deposited. The trace fossils of the Ashin Formation suggest deposition in a deep-marine environment (e.g., Vaziri and Fürsich, 2007). The rapid increase in subsidence would support a rift basin setting.

During the late Triassic, the Cimmerian blocks collided with the southern Eurasian margin and the oceanic basins closed. During the Early Triassic (Olenekian, $248 \mathrm{Ma}$ ago), the strong slab-pull force detached Cimmerian blocks from Gondwana and opened the Neotethys Ocean (Stampfli, 2000). Due to the collision of the Cimmerian blocks with the Eurasian margin, the back-arc basins subsequently closed during the Late Triassic (Şengör, 1979; Stampfli, 2000; Muttoni et al., 2009a, b). Taking into account palaeomagnetic studies of the Central-East Iranian Microcontinent, the Nakhlak region detached from Eurasia probably in the Early Jurassic and was attached to the Cimmerian Blocks and displaced to the present position in Central Iran with $135^{\circ} \mathrm{CCW}$ rotation.

\section{Conclusions}

Our new petrographic and geochemical data provide constraints on the depositional and tectonic setting of the Nakhlak Group:

- Major and trace elements concentrations suggest felsic to intermediate source rocks. Generally, petrographic and geochemical data demonstrate a magmatic arc-related marine depositional basin which was later filled by sediments eroded from the exhumed basement. So, the marine depositional setting changed into a terrestrial depositional setting. Finally, due to extensional tectonics this terrestrial setting turned again into a marine basin. 
- Angular large volcanic fragments in the sandstone samples clearly point to syndepositional volcanic eruptions. Massive fossiliferous limestone beds intercalated with volcano-clastic sandstone and shale beds, especially in the Alam Formation, suggest rapid changes between the times of volcanic activity and quiescent episodes during deposition of Nakhlak Group sediments.

- The presence of fresh volcanic lithics indicates a proximal provenance and low degree of weathering at the source. The detrital material has undergone short transport distances and little sedimentary recycling.

All data support the hypothesis that the Nakhlak Group in Central Iran does not belong to the Cimmerian Block. The sediments of the Nakhlak Group were originally deposited in a basin close to magmatic arc rocks in an active margin setting at the south of Eurasia. The only siliciclastic Triassic sequence in Iran showing similarities in lithology and fossil contents is the Aghdarband Group of Eurasian affinity, exposed in an erosional window around Aghdarband in northeastern Iran. We, therefore, suggest that the Triassic sediments of the Nakhlak Group were deposited in proximity to the Aghdarband basin along the southern margin of Eurasia.

\section{Acknowledgements}

The present paper is a part of the first author's Ph.D. thesis, which is partly supported by the University of Hormozgan; financial support for the first author's research stay in Germany has been provided by the Ministry of Sciences, Researches, and Technology of the Islamic Republic of Iran. Part of the geochemical analyses has been supported financially by the IAS Postgraduate Grant Scheme 2015. We thank Gerald Hartmann for XRF analyses, Klaus Simon for ICP-MS analyses, and Andreas Reimer for LECO elemental analyses. Helpful discussions with Hilmar von Eynatten are very much appreciated. Finally, we are grateful to 
639 Paul R. Eizenhöfer and an anonymous reviewer for some very helpful comments on an earlier 640 draft of the manuscript, which greatly improved the final paper, and to Carita Augustsson for 641 her careful editorial handling.

642

643

644

645

646

647

648

649

650

651

652

653

654

655

656

\section{Appendix A. Supplementary data}

Supplementary data to this article can be found online at http://dx.doi.org/xxx. These data include the sandstone framework composition (QFLdata), trace and rare earth element data, trace element ratios, and graphs illustrating LOI vs. $\mathrm{CaO}$ content from the Nakhlak Group.

\section{References}

Aghanabati, A., 2004. Geology of Iran. Geological Survey of Iran, Tehran, 586 pp. (in Persian).

Agard, P., Omrani, J., Jolivet, L., Whitechurch, H., Vrielynck, B., Spakman, W., Monié, P., Meyer, B., Wortel, R., 2011. Zagros orogeny: a subduction-dominated process. Geological Magazine 148, 692-725.

Alavi, M., Vaziri, H., Seyed Emami, K., Lasemi, Y., 1997. The Triassic and associated rocks of the Nakhlak and Aghdarband areas in central and northeastern Iran as remnants of the southern Turanian active continental margin. Geological Society of America, Bulletin 109, $1563-1575$.

Armstrong-Altrin, J.S., Machain-Castillo, M.L., Rosales-Hoz, L., Carranza-Edwards, A., Sanchez-Cabeza, J.A., Ruíz-Fernández, A.C., 2015. Provenance and depositional history of continental slope sediments in the Southwestern Gulf of Mexico unraveled by geochemical analysis. Continental Shelf Research 95, 15-26. 
661

662

663

664

665

666

667

668

669

670

671

672

673

674

675

676

Bagheri, S., Stampfli, G.M., 2008. The Anarak, Jandaq and Posht-e-Badam metamorphic complexes in Central Iran: new geological data, relationships and tectonic implications. Tectonophysics 451, 123-155.

Balini, M., Nicora, A., Berra, F., Garzanti, F., Levera, M., Mattei, M., Muttoni, M., Zanchi, A., Bollati, I., Larghi, C., Zanchetta, S., Salamati, R., Mossavvari, F., 2009. The Triassic stratigraphic succession of Nakhlak (Central Iran), a record from an active margin. In: Brunet, M.F., Wilmsen, M., Granath, J.W. (Eds.), South Caspian to Central Iran Basins. Geological Society, London, Special Publication 312, pp. 287-321.

Baud, A., Stampfli, G.M., 1989. Tectonogenesis and evolution of a segment of the Cimmerides: the volcano-sedimentary Triassic of Aghdarban (Kopet-Dagh, North-East Iran). In: Şengör, A.M.C. (Eds.), Tectonic Evolution of the Tethyan region. Kluwer, pp. 265-275.

Berberian, M., King, G., 1981. Toward a paleogeographic and tectonic evolution of Iran. Canadian Journal of Earth Sciences 18, 210-265.

Bhatia, M.R., 1983. Plate tectonics and geochemical composition of sandstones. Journal of Geology 91, 611-627.

Bhatia, M.R., 1985. Rare earth element geochemistry of Australian Paleozoic graywackes and mudrocks: provenance and tectonic control. Sedimentary Geology 45, 97-113.

Bhatia, M.R., Crook, K.A.W., 1986. Trace element characteristics of greywackes and tectonic setting discrimination of sedimentary basins. Contributions to Mineralogy and Petrology 92, 181-193.

Busby, C., Fackler-Adams, B.N., Matinson, J., Deoreo, S., 2006. View of an intact oceanic arc, from surficial to mesozonal levels: Cretaceous Alisitos Arc, Baja California. Journal of Volcanology and Geothermal Research 149, 1-46. 
684 Cox, R., Lowe, D.R., 1995. A conceptual review of regional-scale controls on the composition of clastic sediment and the co-evolution of continental blocks and their sediment cover. Journal of Sedimentary Research 65, 1-12.

Critelli, S., 1993. Sandstone detrital modes in the Paleogene Liguride Complex, accretionary wedge of the Southern Apennines (Italy). Journal of Sedimentary Petrology 63, 464-476.

Critelli, S., De Rosa, R., Platt, J.P., 1990. Sandstone detrital modes in the Makran accretionary wedge, southwest Pakistan: Implications for tectonic setting and long-distance turbidite transportation. Sedimentary Geology 68, 241-260.

Critelli, S., Ingersoll, R.V., 1995. Interpretation of neovolcanic versus palaeovolcanic sand grains: an example from Miocene deep-marine sandstone of the Topanga Group (Southern California). Sedimentology 42, 783-804.

Critelli, S., Marsaglia, K.M., Busby, C.J., 2002. Tectonic history of a Jurassic backarc basin sequence (the Gran Cañon Formation) based on compositional modes of tuffaceous deposits. Geological Society of America Bulletin 114, 515-527.

Critelli, S., Muto, F., Perri, F., Tripodi, V., 2017. Interpreting provenance relations from sandstone detrital modes, Southern Italy Foreland Region: stratigraphic record of the Miocene tectonic evolution. Marine and Petroleum Geology 87, 47-59.

Davoudzadeh, M., Seyed-Emami, K., Amidi, M., 1969. Preliminary note on a newly discovered Triassic Sectionnortheast of Anarak (Central Iran), with some remarks on the age of the Metamorphism on the Anarak Region. Geological Survey of Iran Note, $51 \mathrm{pp}$.

Davoudzadeh, M., Seyed-Emami, K., 1972. Stratigraphy of the Triassic Nakhlak Group, Anarak region, Central Iran. Geological Survey of Iran, Report 28, 5-28. 
Davoudzadeh, M., Soffel, H., Schmidt, K., 1981. On the rotation of Central-East-Iran microplate. Neues Jahrbuch für Geologie und Paläontologie, Monatshefte 3, 180-192.

Dickinson, W.R., 1970. Interpreting detrital modes of graywacke and arkose. Journal of Sedimentary Petrology 40, 695-707.

Dickinson, W.R., Suczek, C.A., 1979. Plate tectonics and sandstone compositions. American Association of Petroleum Geologist, Bulletin 63, 2164-2182.

Dickinson, W.R., 1985. Interpreting provenance relations from detrital modes of sandstones. In: Zuffa, G.G. (Eds.), Provenance of arenites. Dordrecht, Reidel, NATO ASI Series 148, pp. $333-361$.

Fedo, C.M., Nesbitt, H.W., Young, G.M., 1995. Unraveling the effects of potassium metasomatism in sedimentary rocks and paleosols, with implications for paleoweathering conditions and provenance. Geology 23, 921-924.

Garver, J.I., Royce, P.R., Smick, T.A., 1996. Chromium and nickel in shale of the Taconic foreland: a case study for the provenance of fine-grained sediments with an ultramafic source. Journal of Sedimentary Research 66, 100-106.

Garzanti, E., Vezzoli, G., 2003. A classification of metamorphic grains in sands based on their composition and grade. Journal of Sedimentary Research 73, 830-837.

Garzanti, E., 2016. From static to dynamic provenance analysis-Sedimentary petrology upgraded. Sedimentary Geology 336, 3-13.

Ghosh, S., Sarkar, S., Ghosh, P., 2012. Petrography and major element geochemistry of the Permo-Triassic sandstones, central India: Implication for provenance in an intracratonic pull- 
Hashemi Azizi, S.H., Rezaee, P., 2014, Lithostratigraphy and lithofacies of the siliciclastic Baqoroq Formation (Middle Triassic), Nakhlak area, Central Iran. In: Rocha, R., Pais, J., Kullberg, J.C., Finney, S. (Eds.), Strati 2013, First international congress on stratigraphy at the cutting edge of stratigraphy. Springer Geology, pp. 463-468.

Hayashi, K., Fujisawa, H., Holland, H.D., Ohmoto, H., 1997. Geochemistry of 1.9 Ga sedimentary rocks from northeastern Labrador, Canada. Geochimica et Cosmochimica Acta $61,4115-4137$.

Holzer, H.F., Ghasemipour, R., 1973. Geology of the Nakhlak Lead Mine area (Anarak District, central Iran). Geological Survey of Iran Report 21, 5-26.

Ingersoll, R.V., Bullard, T.F., Ford, R.L., Grimm, J.P., Pickle, J.D., Sares, S.W., 1984. The effect of grain size on detrital modes: a test of the Gazzi-Dickinson point-counting method. Journal of Sedimentary Petrology 54, 103-116.

Jafarzadeh, M., Harami, R.M., Amini, A., Mahboubi, A., Farzaneh, F., 2013. Geochemical constraints on the provenance of Oligocene-Miocene siliciclastic deposits (Zivah Formation) of NW Iran: implications for the tectonic evolution of the Caucasus. Arabian Journal of Geosciences 7, 4245-4263.

Krystyn, L., Tatzreiter, F., 1991. Middle Triassic ammonoids from Aghdarband (NE-Iran) and their paleobiogeographical significance. Abhandlungen der Geologischen Bundesanstalt $38,139-163$.

Le Maitre, R.W., Streckeisen, A., Zanettin, B., Le Bas, M.J., Bonin, B., Bateman, P., Bellieni, G., Dudek, A., Efremova, S., Keller, J., Lamere, J., Sabine, P.A., Schmid, R., Sørensen, H., Woolley, A.R., 2002. Igneous Rocks: A Classification and Glossary of Terms, 
Recommendations of the International Union of Geological Sciences, Subcommission of the Systematics of Igneous Rocks. Cambridge University Press, pp. 237.

Marsaglia, K.M., Barone, M., Critelli, S., Busby, C., Fackler-Adams, B., 2016. Petrography of volcaniclastic rocks in intra-arc volcano-bounded to fault-bounded basins of the Rosario segment of the Lower Cretaceous Alisitos oceanic arc, Baja California, Mexico. Sedimentary Geology 336, 138-146.

McLennan, S.M. 1989. Rare earth elements in sedimentary rocks: influence of provenance and sedimentary processes. In: Lipin, B.R., McKay, G.A. (Eds.), Geochemistry and Mineralogy of Rare Earth Elements. Mineralogical Society of America, Reviews in Mineralogy 21, 169-200.

McLennan, S.M., Taylor, S.R., McCulloch, M.T., Maynard, J.B., 1990. Geochemical and $\mathrm{Nd}-\mathrm{Sr}$ isotopic composition of deep-sea turbidites: Crustal evolution and plate tectonic associations. Geochimica et Cosmochimica Acta 54, 2015-2050.

McLennan, S.M., Hemming, S., McDaniel, D.K., Hanson, G.N., 1993. Geochemical approaches to sedimentation, provenance and tectonics. In: Johnsson, M.J., Basu, A. (Eds.) Processes Controlling the Composition of Clastic Sediments. Geological Society of America, Special Paper 284, 21-40.

McLennan, S.M., 2001. Relationships between the trace element composition of sedimentary rocks and upper continental crust. Geochemistry, Geophysics, Geosystems 2(4), DOI: 10.1029/2000GC000109

McLennan, S.M., Bock, B., Hemming, S.R., Hurowitz, J.A., Lev, S.M., McDaniel, K., 2003. The role of provenance and sedimentary processes in the geochemistry of sedimentary rocks. In: Lentz, D.R. (Eds.), Geochemistry of Sediments and Sedimentary Rocks: Evolutionary 
considerations to Mineral Deposit-Forming Environments. Geological Association of Canada, Geo Text 4, 7-38.

Meinhold, G., Kostopoulos, D., Reischmann, T., 2007. Geochemical constraints on the provenance and depositional setting of sedimentary rocks from the islands of Chios, Inousses and Psara, Aegean Sea, Greece: implications for the evolution of Palaeotethys. Journal of the Geological Society of London 164, 1145-1163.

Muttoni, G., Gaetani, M., Kent, D.V., Sciunnach, D., Angiolini, L., Berra, F., Garzanti, E., Mattei, M., Zanchi, A., 2009a. Opening of the Neo-Tethys Ocean and the Pangea B to Pangea A transformation during the Permian. GeoArabia 14, 17-48.

Muttoni, G., Mattei, M., Balini, M., Zanchi, A., Gaetani, M., Berra, F., 2009b. The drift history of Iran from the Ordovician to the Triassic. In: Brunet, M.F., Wilmsen, M., Granath, J.W. (Eds.), South Caspian to Central Iran Basins. Geological Society, London, Special Publication 312, pp. 7-29.

Nesbitt, H.W., Young, G.M., 1982. Early Proterozoic climates and plate motions inferred from major element chemistry of lutites. Nature 299, 715-717.

Nesbitt, H.W., 2003. Petrogenesis of siliciclastic sediments and sedimentary rocks. In: Lentz, D.R. (Eds.), Geochemistry of Sediments and Sedimentary Rocks: Evolutionary considerations to Mineral Deposit-Forming Environments. Geological Association of Canada, Geo Text 4, pp. 39-51.

Perri, F., Critelli, S., Cavalcante, F., Mongelli, G., Sonnino, M., Dominici, R., De Rosa, R., 2012. Provenance signatures for the Miocene volcaniclastic succession of the Tufiti di Tusa Formation, southern Apennines, Italy. Geological Magazine 149, 423-442. 
795 Pettijohn, F.J., Potter, P.E., Siever, R., 1987. Sand and Sandstone. $2^{\text {nd }}$ Edition, Springer796 Verlag, New York, 553 pp.

797 Potter, E.P., Maynard, J.B., Depetris, P.J., 2005. Mud and mudstone: Introduction and 798 overview. Springer-Verlag, Berlin, 297 pp.

799 Roser, B.P., Korsch, R.J., 1986. Determination of tectonic setting of sandstone-mudstone 800 suites using $\mathrm{SiO}_{2}$ content and $\mathrm{K}_{2} \mathrm{O} / \mathrm{Na}_{2} \mathrm{O}$ ratio. Geology 94, 635-650.

801 Roser, B.P., Korsch, R.J., 1988. Provenance signatures of sandstone-mudstone suites 802 determined using discriminant function analysis of major-element data. Chemical Geology 803 $67,19-139$.

Roser, B.P., Coombs, D.S., Korsch, R.J., Campbell, J.D., 2002. Whole-rock geochemical 805 variation and evolution of the arc-derived Murihiku Terrane, New Zealand. Geological Magazine 139, 665-685.

Rudnick, R.L., Gao, S., 2003. Composition of the continental crust. In: Holland, H.D., Turekian, K.K. (Eds.), Treatise on Geochemistry. Elsevier-Pergamon, Oxford, pp. 1-64.

Ruttner, A.W., 1984. The pre-Liassic basement of the eastern Kopet Dag Range. Neues 810 Jahrbuch für Geologie und Paläontologie, Abhandlungen 168, 256-268.

811 Ruttner, A.W., 1993. Southern borderland of Triassic Laurasia in north-east Iran. 812 Geologische Rundschau 82, 110-120.

813 Saidi, A., Brunet, M.F., Ricou, L.E., 1997. Continental accretion of the Iran Block to Eurasia 814 as seen from Late Paleozoic to Early Cretaceous subsidence curves. Geodinamica Acta 10, $815 \quad 198-208$. 
Salminen, R., Batista, M.J., Bidovec, M., Demetriades, A., De Vivo, B., De Vos, W., Duris, M., Gilucis, A., Gregorauskiene, V., Halamić, J., Heitzmann, P., Lima, A., Jordan, G., Klaver, G., Klein, P., Lis, J., Locutura, J., Marsina, K., Mazreku, A., O'Connor, P. J., Olsson, S.Å., Ottesen, R.-T., Petersell, V., Plant, J.A., Reeder, S., Salpeteur, I., Sandström, H., Siewers, U., Steenfelt, A., Tarvainen, T., 2005. Geochemical atlas of Europe. Part 1: Background information, methodology and maps. Geological Survey of Finland, Espoo, 526 pp.

Schmidt, K., Soffel, H.C., 1983. Mesozoic-Cenozoic geological events in Central-East-Iran and their relation to palaeomagnetic results. Geological Survey of Iran, Report 51, 27-35.

Şengör, A.M.C., 1979. Mid-Mesozoic closure of Tethys and its implications. Nature 279, $590-593$.

Seyed-Emami, K., 1971. A summary of the Triassic in Iran. Geological Survey of Iran, Report 20, 41-53.

Seyed-Emami, K., 2003. Triassic of Iran. Facies 48, 91-106.

Sharkovski, M., Susov, M., Krivyakin, B., 1984. Geology of the Anarak area (Central Iran). Explanatory Text of the Anarak Quadrangle Map 1:250000. Geological Survey of Iran, V/O Tecnoexport USSR Ministry of Geology, Reports 19.

Soffel, H.C., Förster, H.G., 1984. Polar Wander Path of the Central-East-Iran Microplate including new results. Neues Jahrbuch für Geologie und Paläontologie, Abhandlungen 168, $165-172$.

Soffel, H.C., Davoudzadeh, M., Rolf, C., Schmidt, S., 1996. New palaeomagnetic data from Central Iran and a Triassic palaeoreconstruction. Geologische Rundschau 85, 293-302. 
Stampfli, G.M., 2000. Tethyan oceans. In: Bozkurt, E., Winchester, J.A., Piper, J.D.A. (Eds.), Tectonics and Magmatism in Turkey and the Surrounding Area. Geological Society, London, Special Publication 173, pp. 1-23.

Stampfli, G.M., Borel, G.D., 2002. A plate tectonic model for the Paleozoic and Mesozoic constrained by dynamic plate boundaries and restored synthetic oceanic isochrones. Earth and Planetary Science Letters 196, 17-33.

Stöcklin, J., Eftekhar-Nezhad, J., Hushmandzadeh, A., 1965. Geology of the Shotori Range (Tabas area, East Iran). Geological Survey of Iran, Report 3, 1-69.

Stöcklin, J., 1968. Structural history and tectonics of Iran: A review. The American Association of Petroleum Geologists, Bulletin 52, 1229-1258.

Taylor, S.R., McLennan, S.M., 1985. The Continental Crust: Its Composition and Evolution. Blackwell, Oxford, 312 pp.

Tozer, E.T., 1972. Triassic ammonoids and Daonella from the Nakhlak Group, Anarak region, Central Iran. Geological Survey of Iran, Report 28, 29-69.

Vaziri, S.H., Fürsich, F.T., 2007. Middle to Upper Triassic deep-water trace fossils from the Ashin Formation, Nakhlak Area, Central Iran. Journal of Sciences, Islamic Republic of Iran, $18,263-268$.

Vaziri, S.H., 2011a. Sedimentary structures and depositional environment of the Ashin Formation in Nakhlak area, Central Iran. Iranian Journal of Earth Sciences (IJES), Islamic Azad University, Mashhad Branch, 3, 253-263. 
Vaziri, S.H., 2011b. A review on Late Scythian to Middle Anisian ammonoids from the Alam Formation in Nakhlak area, Central Iran. Journal of Sciences (Islamic Azad University) 21, $201-212$.

Vaziri, S.H., 2012. Geological map of Iran, Nakhlak mine, 1:25,000. Geological Survey and Mineral Exploration of Iran.

Vaziri, S.H., Fürsich, F.T., Kohansal-Ghadimvand, N., 2012. Facies analzsis and depositional environments of the Upper Cretaceous Sadr unit in the Nakhlak area, Central Iran. Revista Mexicana de Ciencias Geológicas 29, 384-397.

Verma, S.P., Armstrong-Altrin, J.S., 2013. New multi-dimensional diagrams for tectonic discrimination of siliciclastic sediments and their application to Precambrian basins. Chemical Geology 355, 117-180.

Verma, S.P., Armstrong-Altrin, J.S., 2016. Geochemical discrimination of siliciclastic sediments from active and passive margin settings. Sedimentary Geology 332, 1-12.

von Eynatten, H., 2003. Petrography and chemistry of sandstones from the Swiss Molasse Basin: an archive of the Oligocene to Miocene evolution of the Central Alps. Sedimentology $50,703-724$.

Walker, R., Jackson, J., 2004. Active tectonics and late Cenozoic strain distribution in central and eastern Iran. Tectonics 23, TC5010. DOI:10.1029/2003TC001529

Weltje, G.J., 2006. Ternary sandstone composition and provenance: an evaluation of the Dickinson model. In: Buccianti, A., Mateu-Figueras, G., Pawlowsky-Glahn V. (Eds.), Compositional Data Analysis in the Geosciences: From Theory to Practice. Geological Society, London, Special Publication 264, 79-99. 
Wendt, J., Kaufmann, B., Belka, Z., Farsan, N., Bavandpur, A.K., 2005. Devonian/Lower Carbonifeous stratigraphy, facies patterns and palaeogeography of Iran Part II. Northern and Central Iran. Acta Geologica Polonica 55, 31-97.

Zanchi, A., Zanchetta, S., Garzanti, E., Balini, M., Berra, F., Mattei, M., Muttoni, G., 2009. The Cimmerian evolution of the Nakhlak-Anarak area, Central Iran, and its bearing for the reconstruction of the history of the Eurasian margin. In: Brunet, M.F., Wilmsen, M., Granath, J.W. (Eds.), South Caspian to Central Iran Basins. Geological Society, London, Special Publication 312, pp. 261-286.

Zuffa, G.G., 1985. Optical analyses of arenites: influence of methodology on compositional results. In: Zuffa, G.G. (Eds.), Provenance of Arenites, NATO-ASI Series 148, pp. 165-189.

\section{Figure captions}

Figure 1. Tectonic setting of Iran modified after Berberian and King (1981) and Aghanabati (2004). The study area (red frame) is located at the southwestern end of GKDFS, in Yazd block, Central Iran. GKDFS: Great Kavir-Doruneh fault system (For interpretation of the reference to colour in this figure legend, the reader is referred to the web version of this article).

Figure 2. Geological map of the Nakhlak Mountain (redrawn from Vaziri, 2012) showing the Alam, Baqoroq, and Ashin formations. The studied sections are illustrated by black solid lines. The location of the Nakhlak mine and the way to Anarak town are also shown. 
Figure 3. QFL diagram for classification of detrital modes of sandstones (Garzanti, 2016, after Weltje, 2006).

Figure 4. Petrographic photomicrographs were taken in crossed polarized light of representative sandstone samples. (a) Feldspatho-volcanolithic sandstone from the Alam Formation (sample AN82) showing microlitic and lathwork fragments and some fresh angular quartz grains with straight extinction and some embayment. Three volcano-clastic fragments are large, showing angular boundaries; one on the right side showing amygdules filled with chlorite (close up inset photomicrograph). (b) Feldspatho-volcanolithic sandstone from the Alam Formation (sample AN15) showing microlitic fragments, microgranular fragments recrystallized from volcanic glass, and K-feldspar grains. (c) Feldspathovolcanolithic sandstone from the Alam Formation (sample AN109) showing lathwork fragments and recrystallized vitric homogenous fragments in a diagenetically grown calcite cement. (d) Arkosic arenite of the Alam Formation (sample AN48) showing large unweathered K-feldspar and plagioclase. (e) Quartzolithic sandstone from the Baqoroq Formation (sample B25) showing polycrystalline quartz grains in contact with volcanic fragments, mostly at the lower part and one quartz-muscovite schist fragment at the right side. (f) A metamorphic pebble (mylonite), muscovite-quartz schist with distinct foliation from the Baqoroq Formation (sample cg2). (g) Quartzolithic sandstone from the Baqoroq Formation (sample B25) showing a large microlitic volcanic fragment at the top and one large carbonate fragment (oolitic limestone) in the middle. h) Quartzofeldspathic sandstone from the Ashin Formation (sample AS16) showing large almost fresh K-feldspar (mostly sanidine) and fresh angular quartz grains with straight extinction. Qz $=$ quartz, P-Qz $=$ polycrystalline quartz, $\mathrm{Lv}=$ volcano-clastic fragment, $\mathrm{Lsm}=$ metasedimentary clast, $\mathrm{Ls}=$ sedimentary clast, $\mathrm{C}=$ calcite cement, $\mathrm{Kfs}=\mathrm{K}$-feldspar, $\mathrm{Plg}=$ plagioclase. 
Figure 5. (a) Multi-element diagrams for siliciclastic sedimentary rocks from Nakhlak Group. Concentrations are normalized against the upper continental crust composition (UCC,

930

931

932

933

934

935

936

937

938

939

940

941

942

Figure 6. (a) Plot of CIA vs. ICV of the siliciclastic sedimentary rocks of Nakhlak Group (Potter et al., 2005). (b) A-CN-K diagram (after Nesbitt and Young, 1982) for the siliciclastic sedimentary rocks of Nakhlak Group. Indices and mineral compositions after Nesbitt and Young (1982): $\mathrm{A}=\mathrm{Al}_{2} \mathrm{O}_{3} ; \mathrm{CN}=\mathrm{CaO}^{*}+\mathrm{Na}_{2} \mathrm{O}$ (where ${ }^{*}$ indicates correction for carbonates) and $\mathrm{K}$ is $\mathrm{K}_{2} \mathrm{O}$ (molar proportions). $\mathrm{Pl}=$ plagioclase, $\mathrm{Sm}=$ smectite, $\mathrm{Ka}=$ kaolinite, $\mathrm{Gb}=$ gibbsite, $\mathrm{Chl}=$ chlorite, $\mathrm{Mu}=$ muscovite, $\mathrm{Ksp}=\mathrm{K}$-feldspar. $\mathrm{PAAS}=$ Post Archean Australian Shale. Crossed linked by the solid line are average volcanic rock compositions from Roser et al. (2002). For an explanation of symbols see Figure 4 (filled symbols $=$ sandstones, open symbols $=$ shales $).$

Figure 7. Discrimination diagrams illustrating weathering and sediment recycling. (a) Th/U vs. Th diagram after McLennan et al. (1993). (b) $\mathrm{Th} / \mathrm{Sc}$ vs. $\mathrm{Zr} / \mathrm{Sc}$ diagram after McLennan et al. (1993). For an explanation of symbols see Figure 4 (filled symbols $=$ sandstones, open symbols $=$ shales $)$.

Figure 8. (a) $\mathrm{TiO}_{2}$ vs. $\mathrm{Zr}$ diagram suggesting felsic to intermediate composition for the Nakhlak Group after Hayashi et al. (1997). (b) Cr/V vs. Y/Ni diagram after McLennan et al. 
950 (1993). (c) Chemical classification of the volcanic rocks based on total alkalis vs. silica

(TAS) after Le Maitre et al. (2002). For an explanation of symbols see Figure 4 (filled symbols $=$ sandstones, open symbols $=$ shales $)$.

Figure 9. Triangular plots (after Weltje, 2006) showing mean framework modes for sandstones from the Nakhlak Group, illustrating derivation from different types of provenance: Q: total quartzose grains $(\mathrm{Qm}+\mathrm{Qp}), \mathrm{Qm}$ : monocrystalline, Qp: polycrystalline, F: total feldspar grains, L: total unstable lithic fragments, Lt: total polycrystalline lithic fragments, including Qp, Lvm: total volcanic-metavolcanic rock fragments, Lsm: unstable sedimentary-metasedimentary rock fragments, P: plagioclase grains, K: K-feldspar grains. For an explanation of symbols see Figure 4.

Figure 10. Multidimensional diagram (a) for high-silica and (b) low-silica clastic sediments of Nakhlak Group after Verma and Armstrong-Altrin (2013). For an explanation of symbols see Figure $4($ filled symbols $=$ sandstones, open symbols $=$ shales $)$.

Figure 11. (a) Tectonic discrimination diagram for the Nakhlak Group after Roser and Korsch (1986). PM - Passive margin, ACM - Active continental margin, OIA - Oceanic island arc. (b) Major element (M) based multidimensional discriminant function diagram and (c) Combined major and trace element (MT) based multidimensional discriminant function diagram for the discriminant of active and passive settings after Verma and Armstrong-Altrin (2016). 
Figure 12. Composite section of the Nakhlak Group showing the position of sandstone samples, the petrographic composition Qt-F-L (total quartz grains include chert-feldsparlithic fragments), VRF (volcanic rock fragment), and MRF (metamorphic rock fragment) bar diagrams. Synsedimentary uplifting movements in the source area are shown by asterisks.

\section{Table}

Table 1. Major elements on a carbonate-free basis, LECO data and calculated indices (CIA and ICV) of sandstone and shale samples from the Nakhlak Group. Upper continental crust (UCC) values from Rudnick and Gao (2003) are for comparison. 


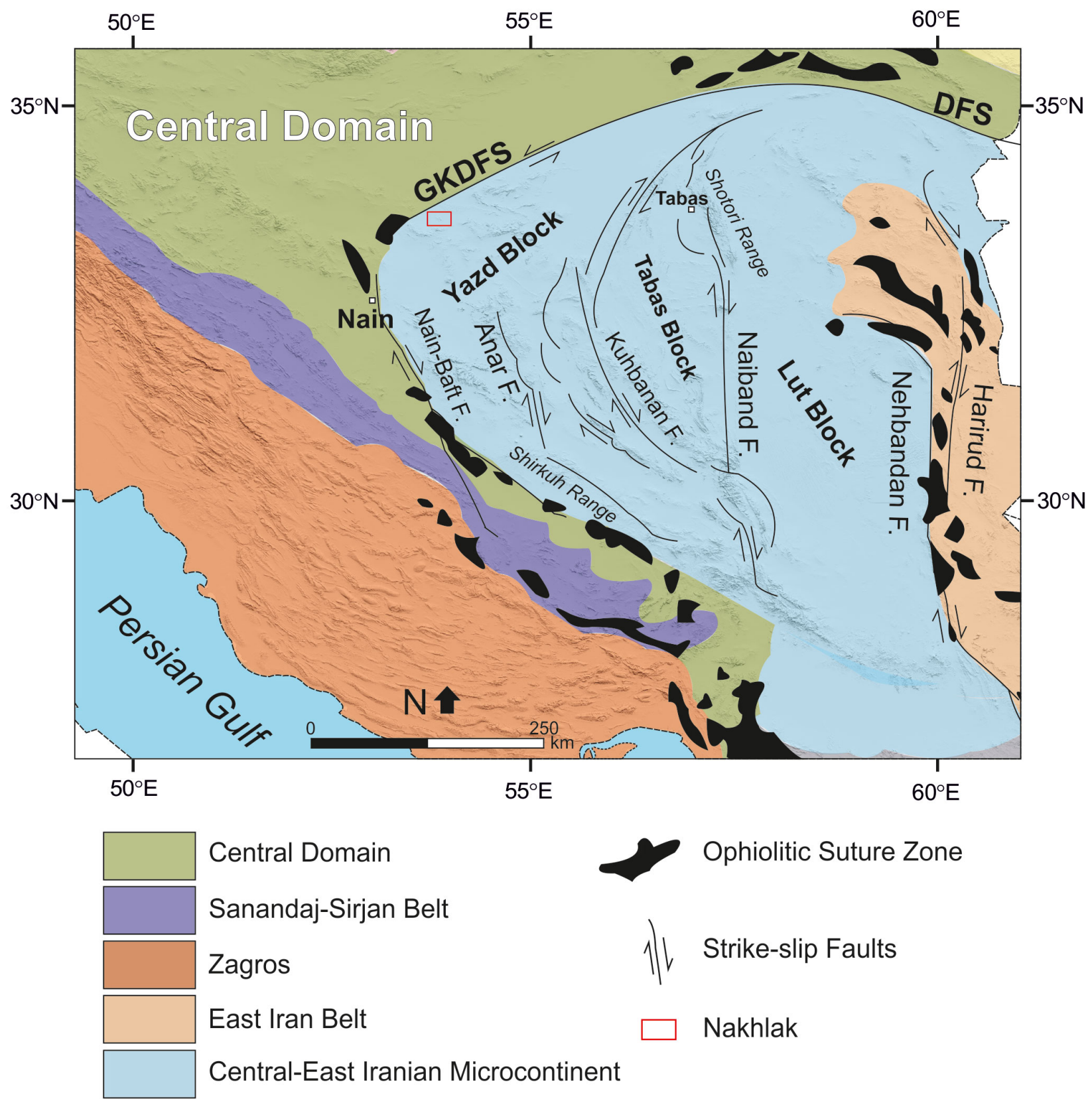

Figure 1 


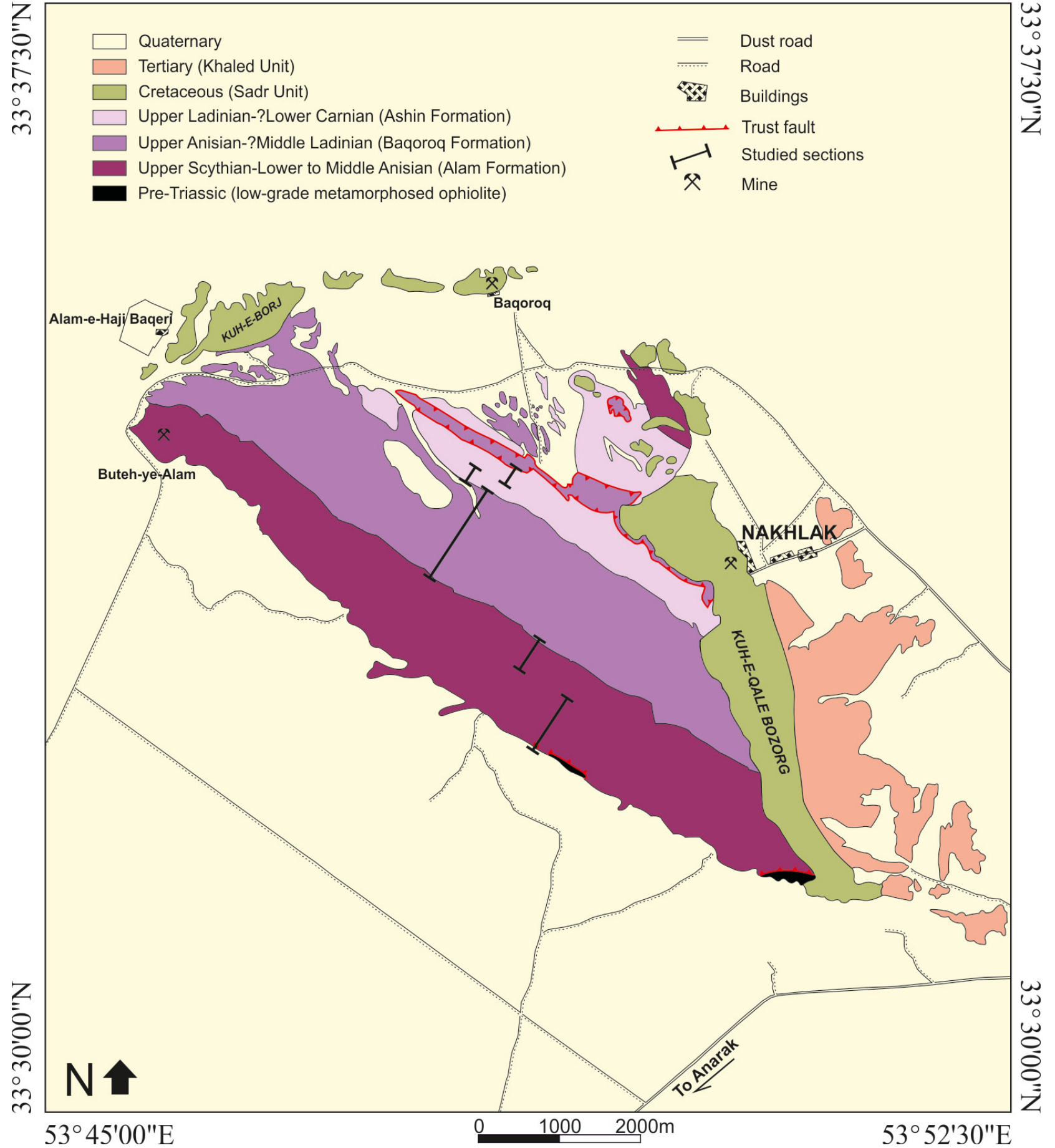

Figure 2 


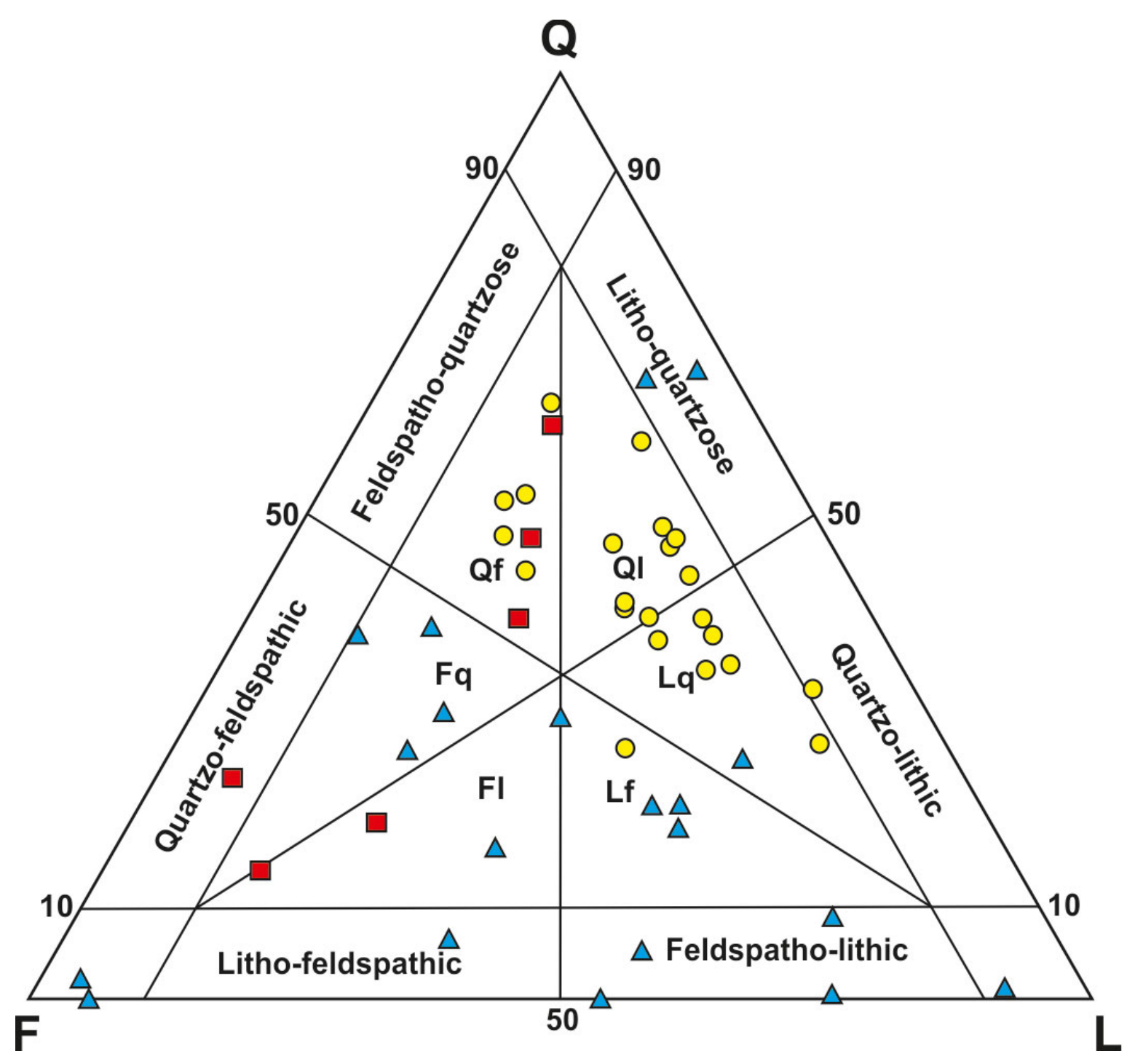

\section{Key}

Ashin Formation

Ladinian-?Lower Carnian

Baqoroq Formation

Upper Anisian-?Lower Ladinian

Alam Formation

Upper Olenekian-Anisian

Figure 3 

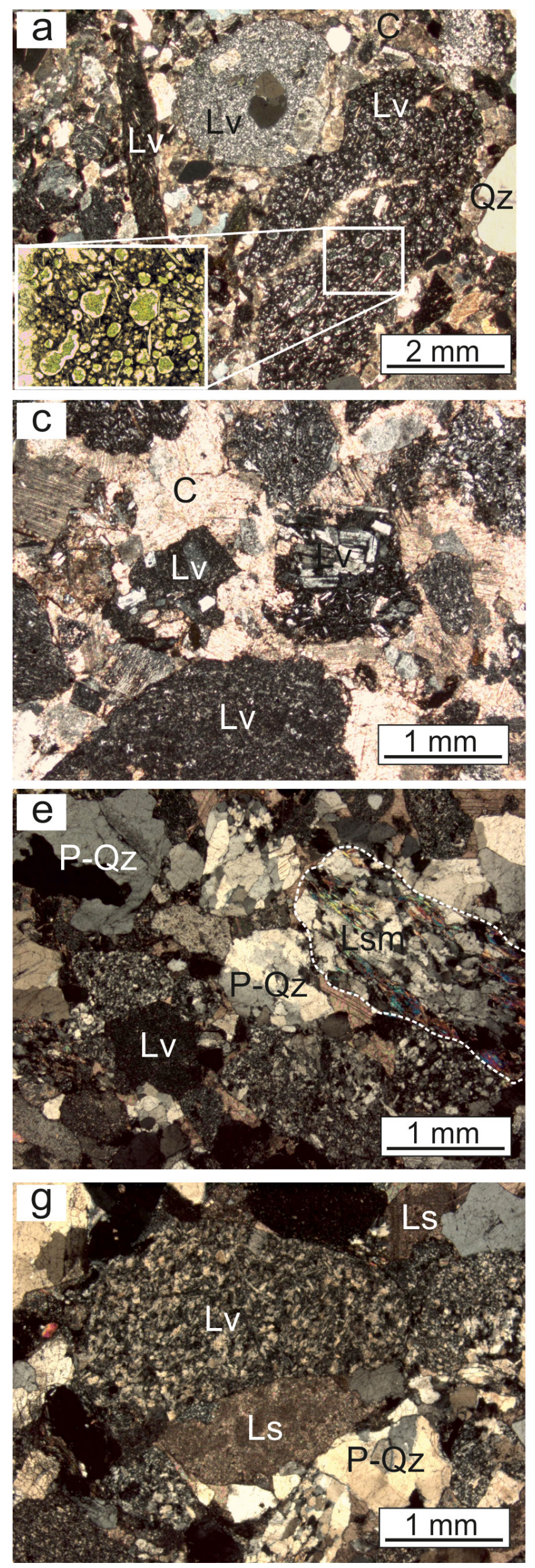

(1)
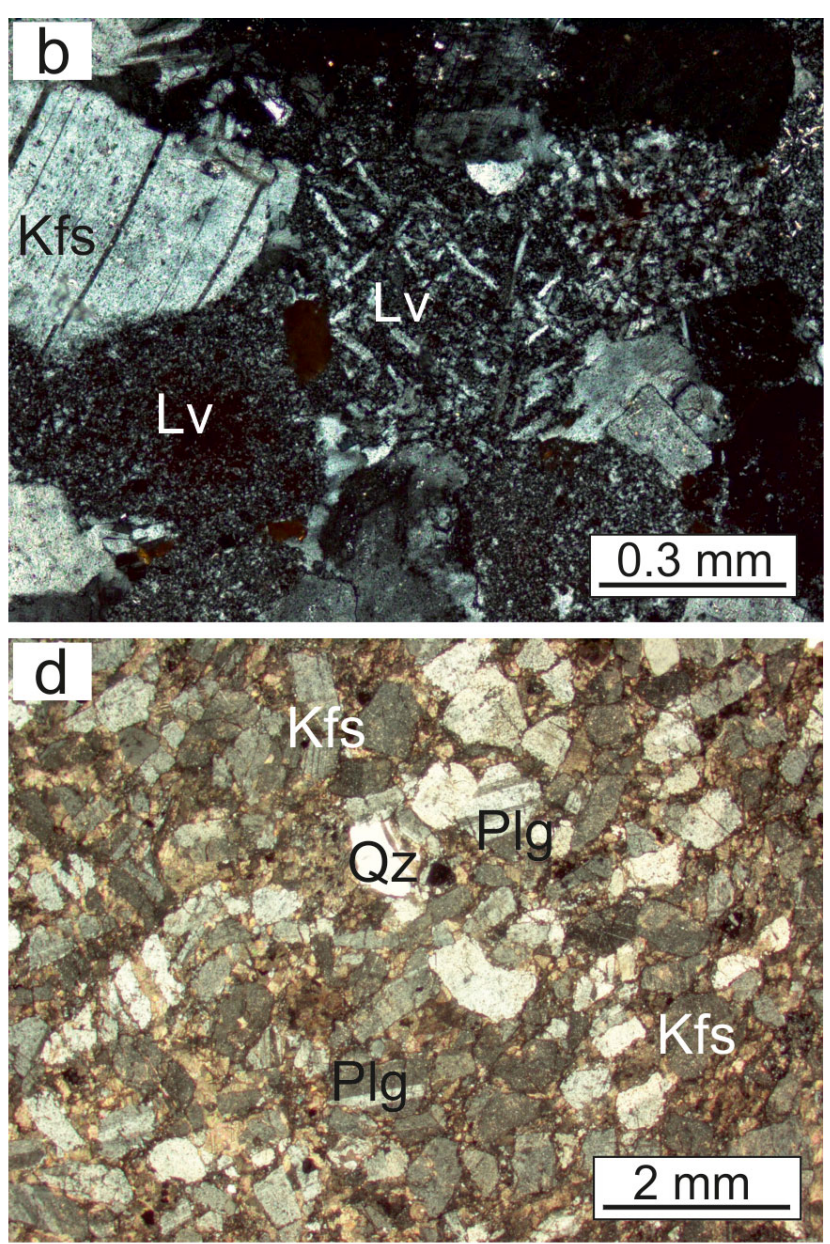

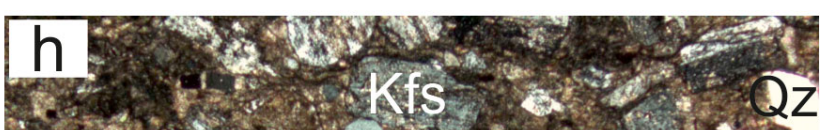

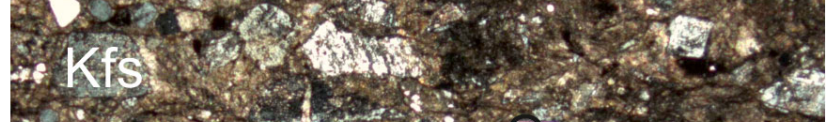

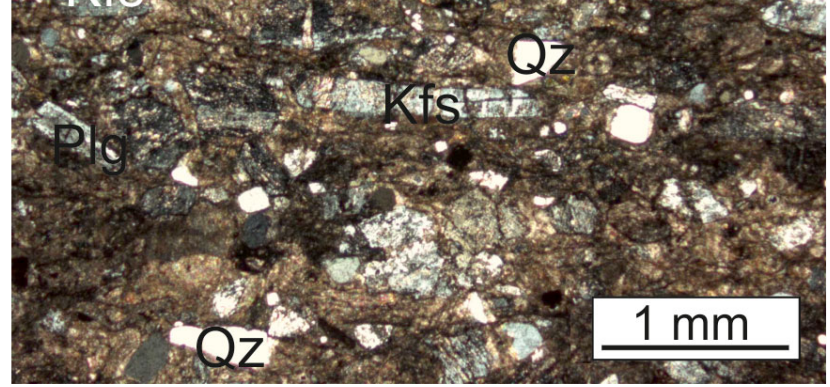



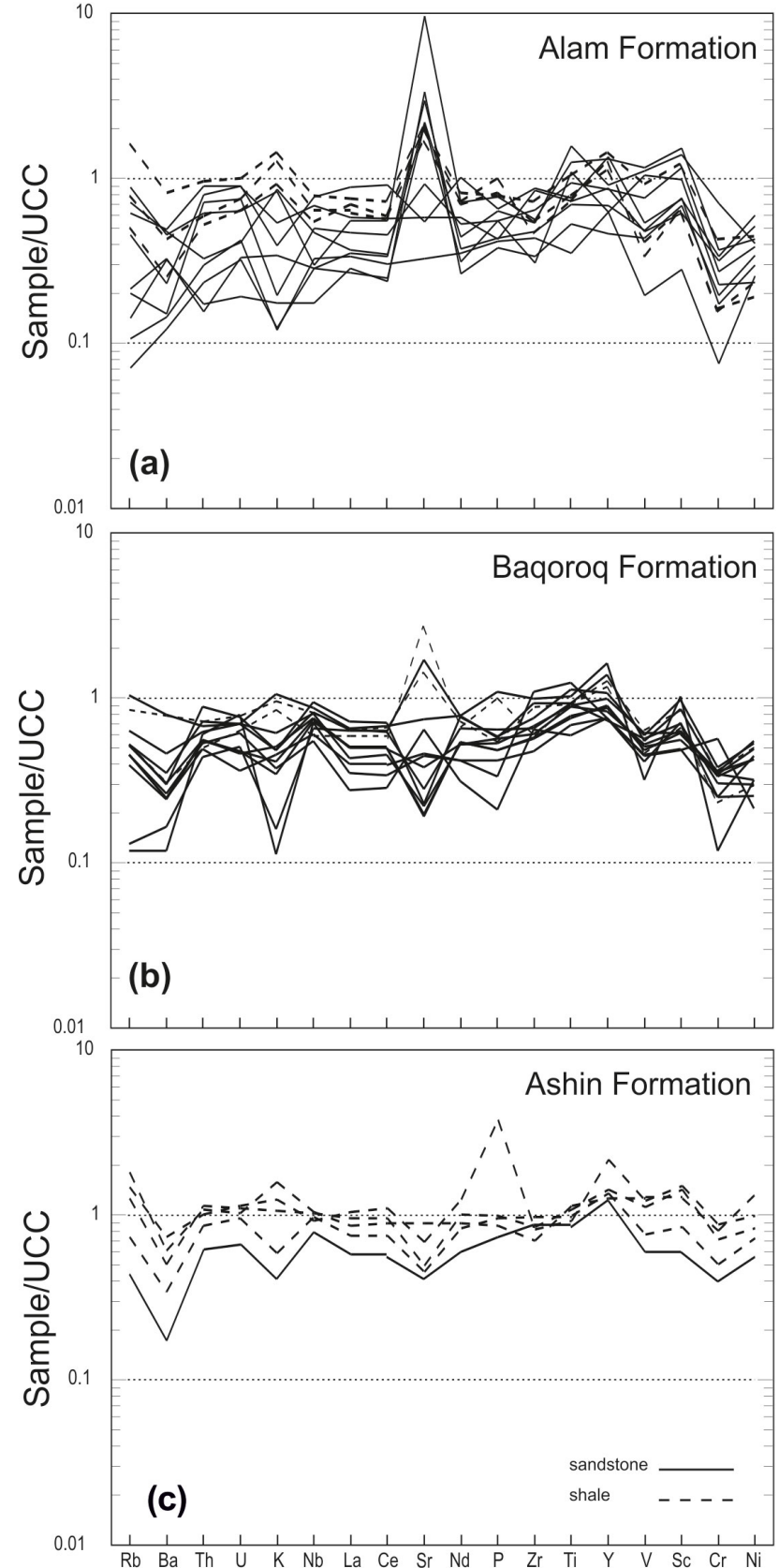
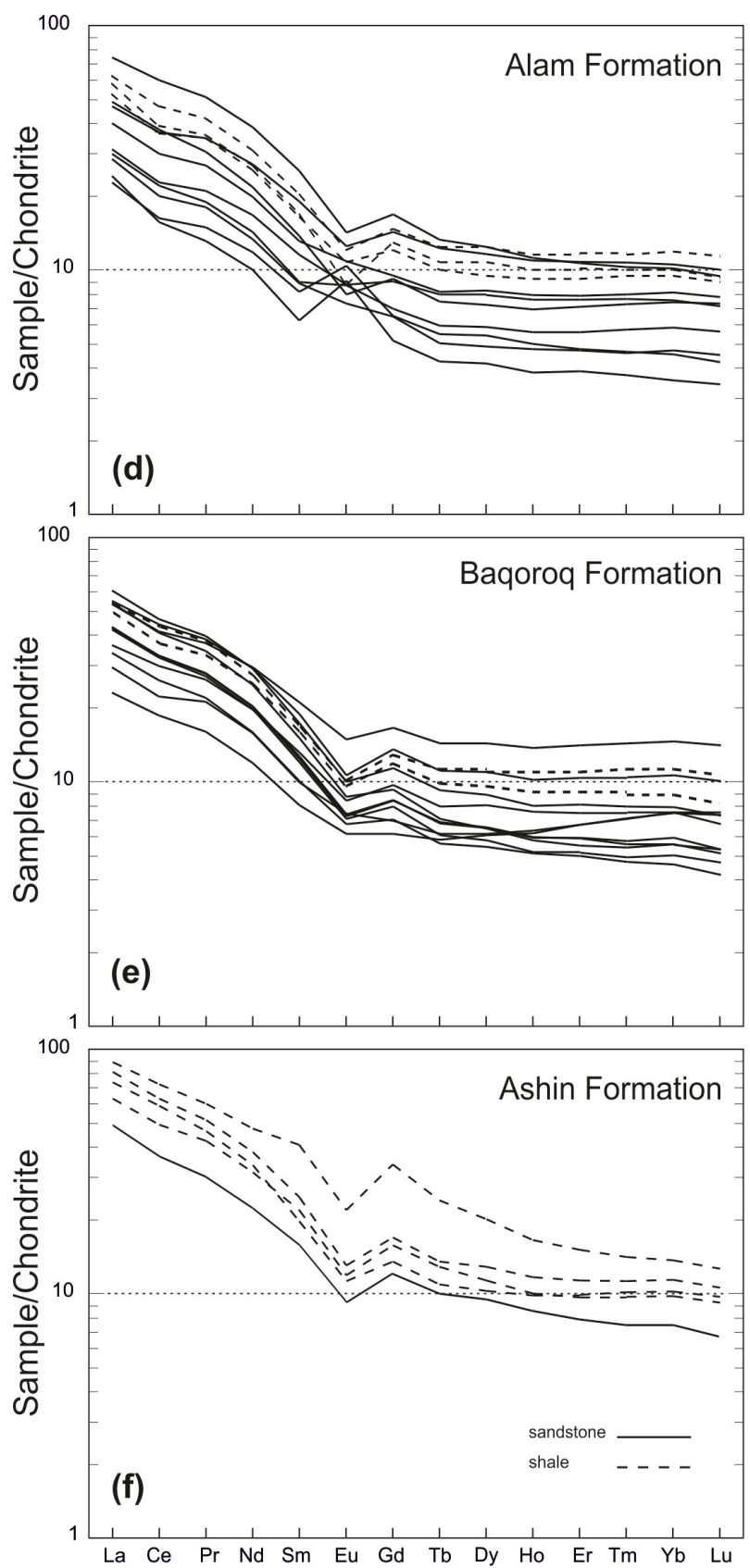

Figure 5 

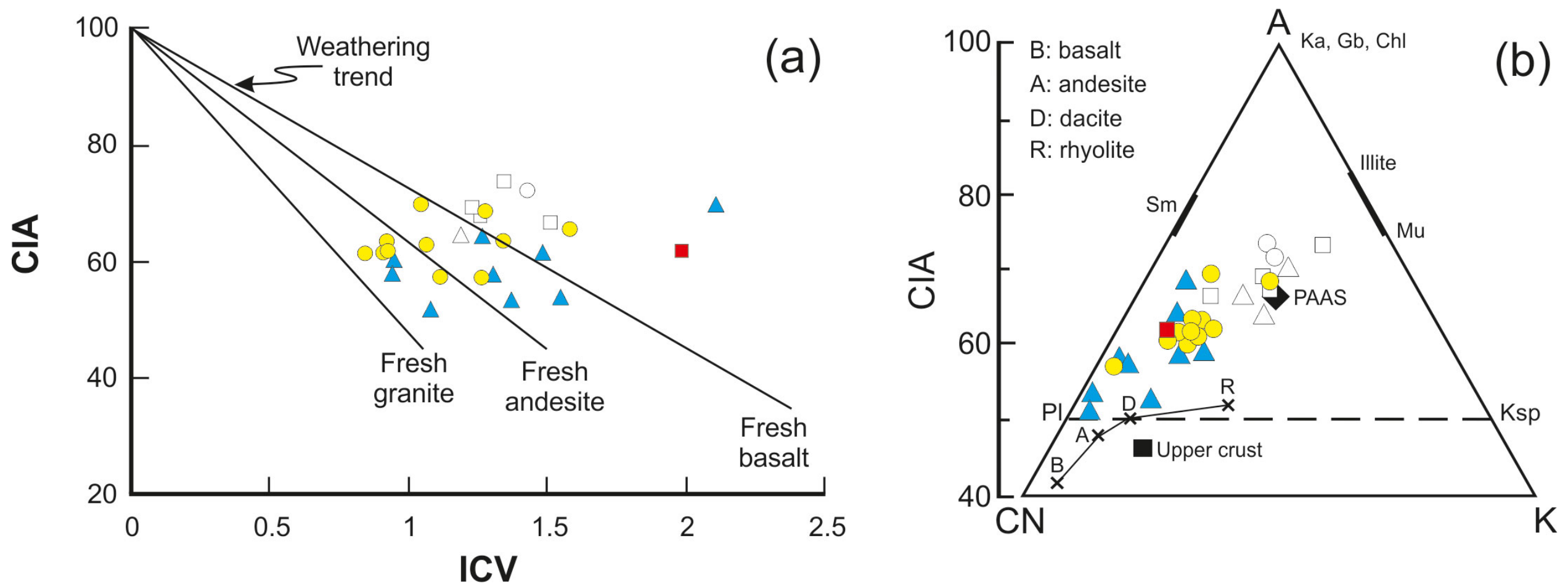

Figure 6 

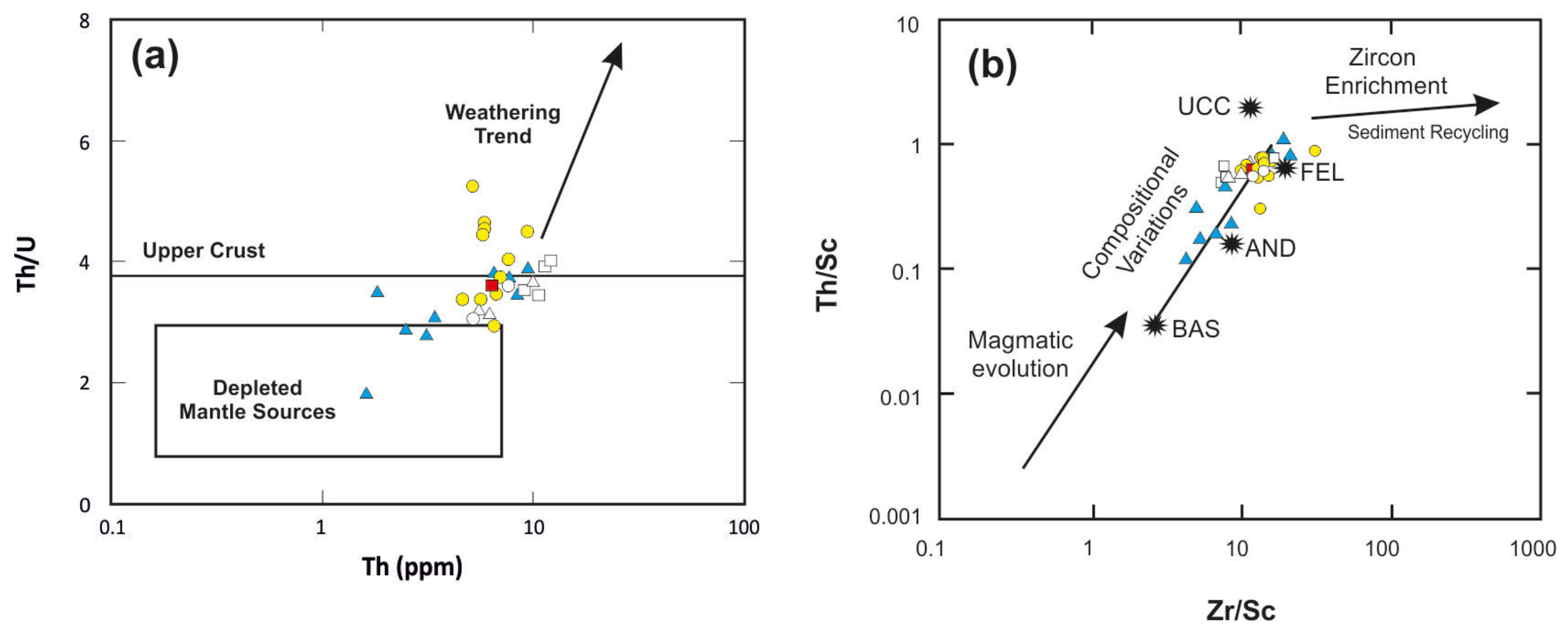

Figure 7 

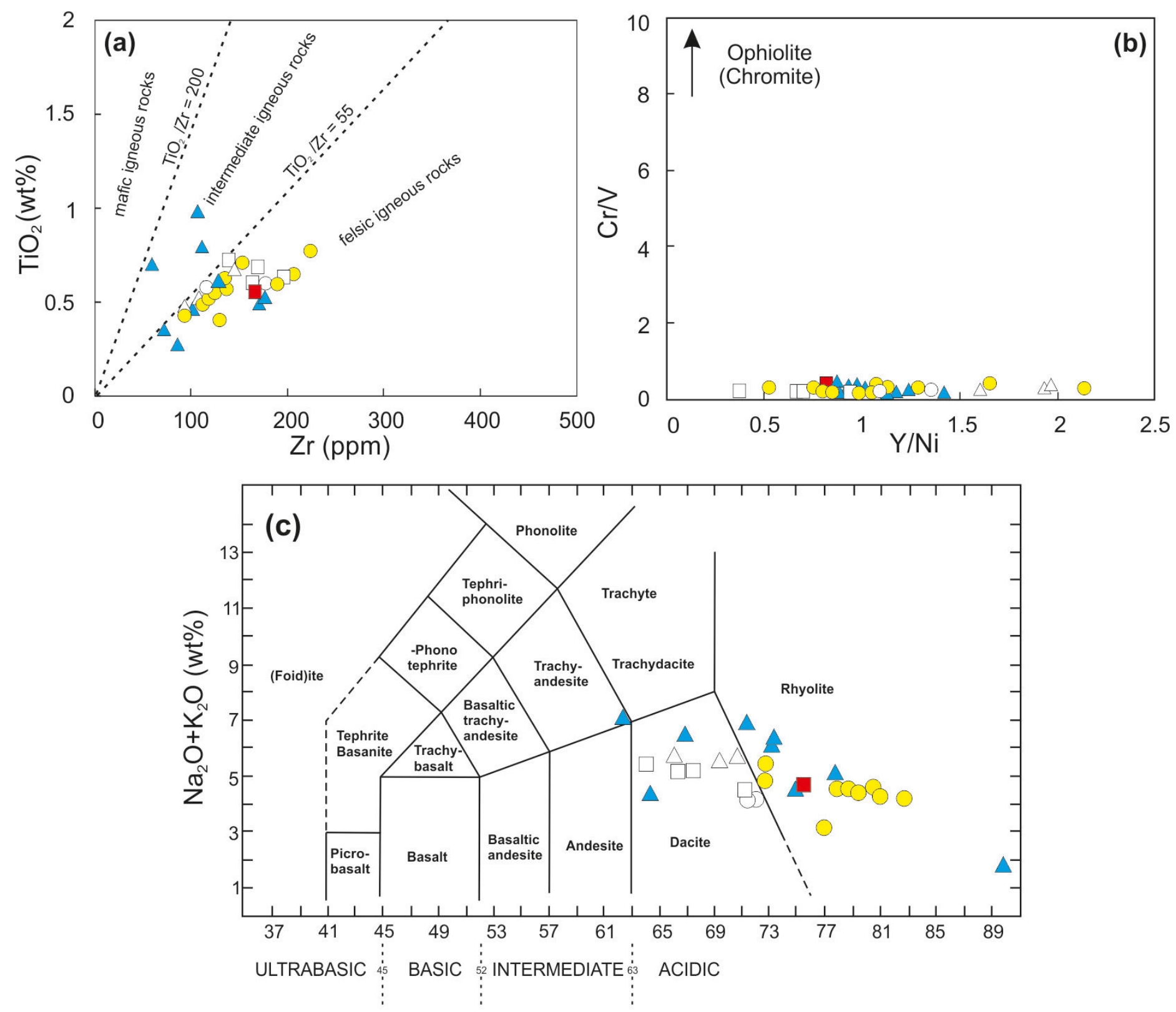

$\mathrm{SiO}_{2}(\mathrm{wt} \%)$

Figure 8 

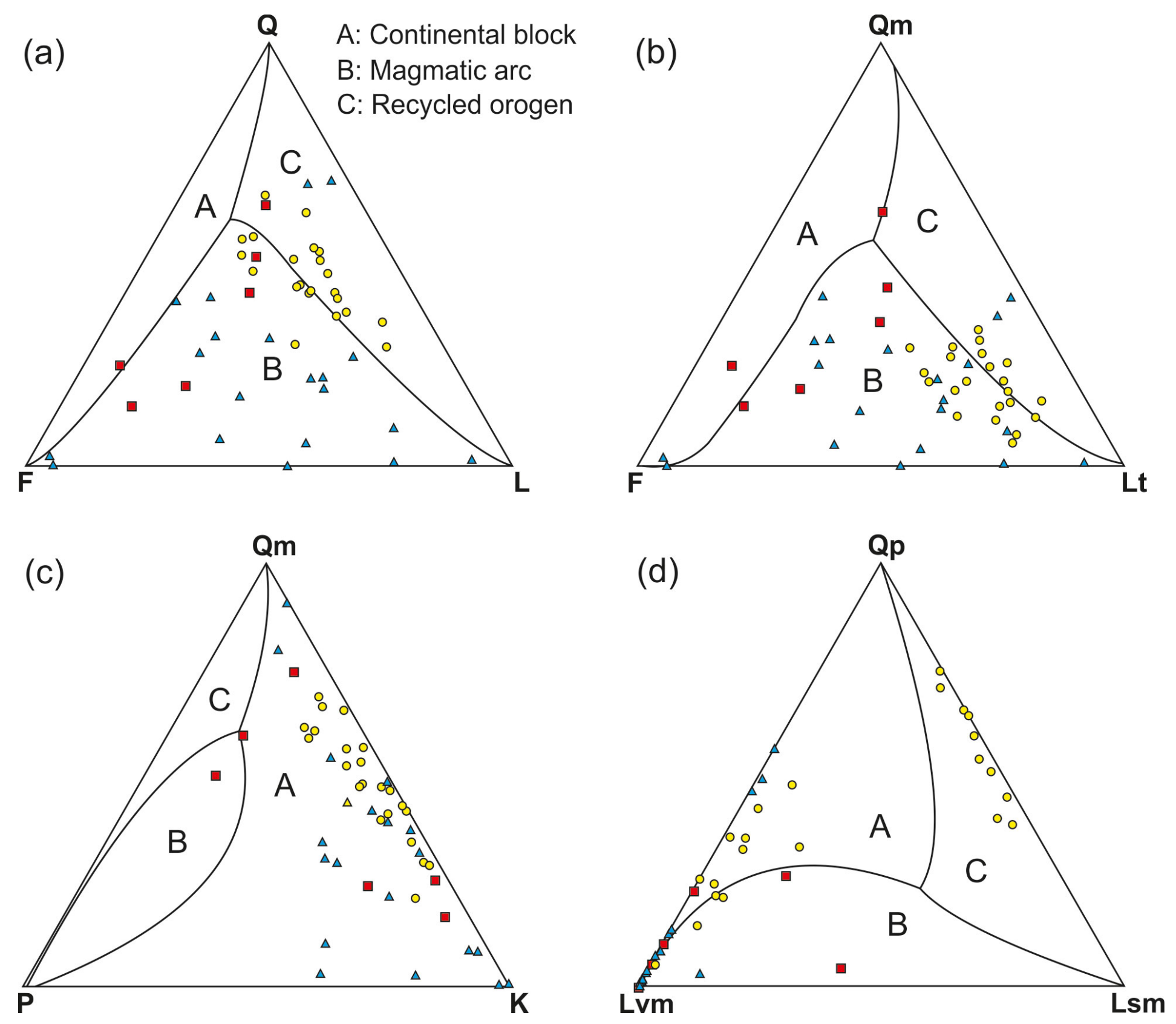

Figure 9 
(a)

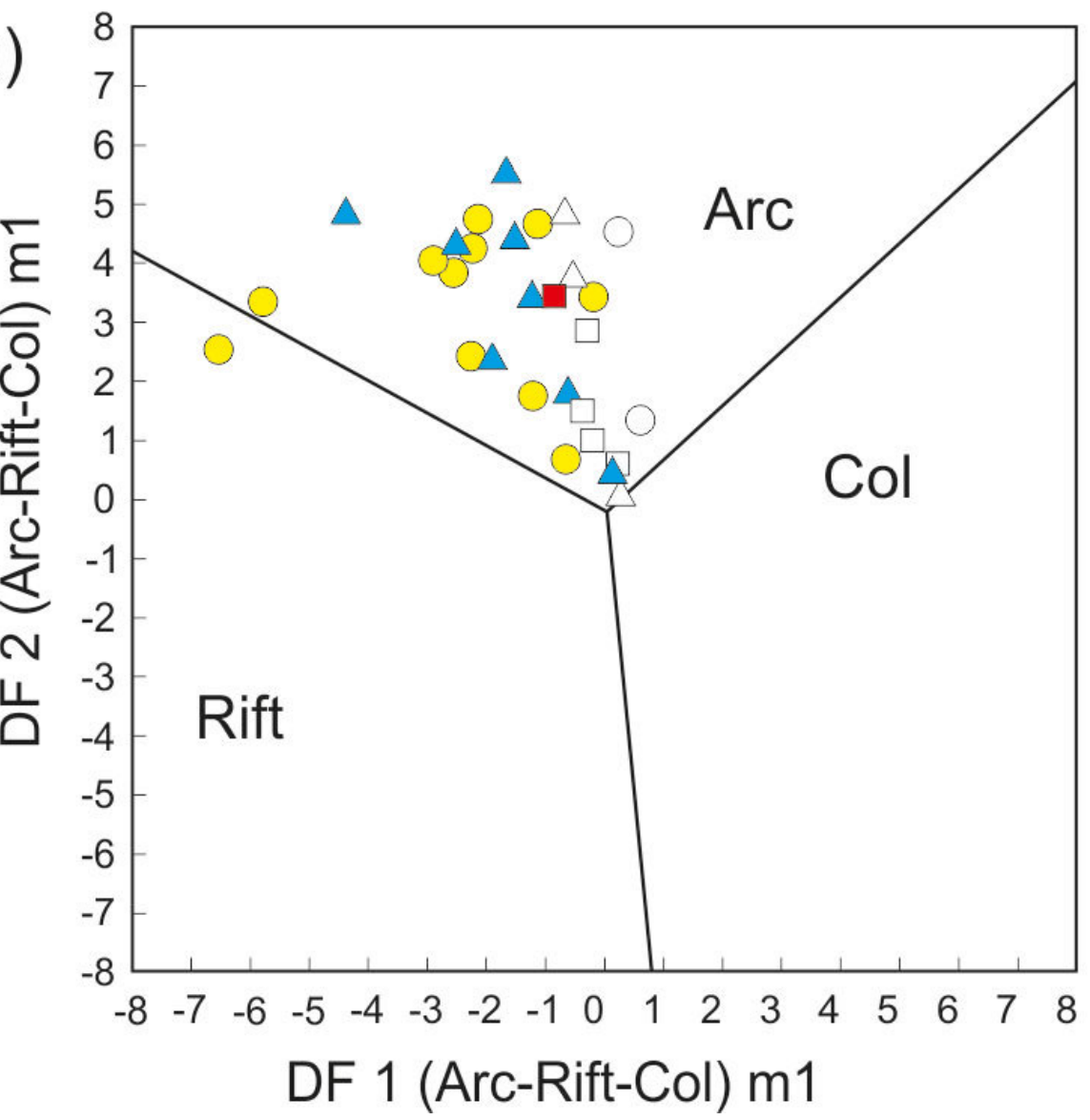

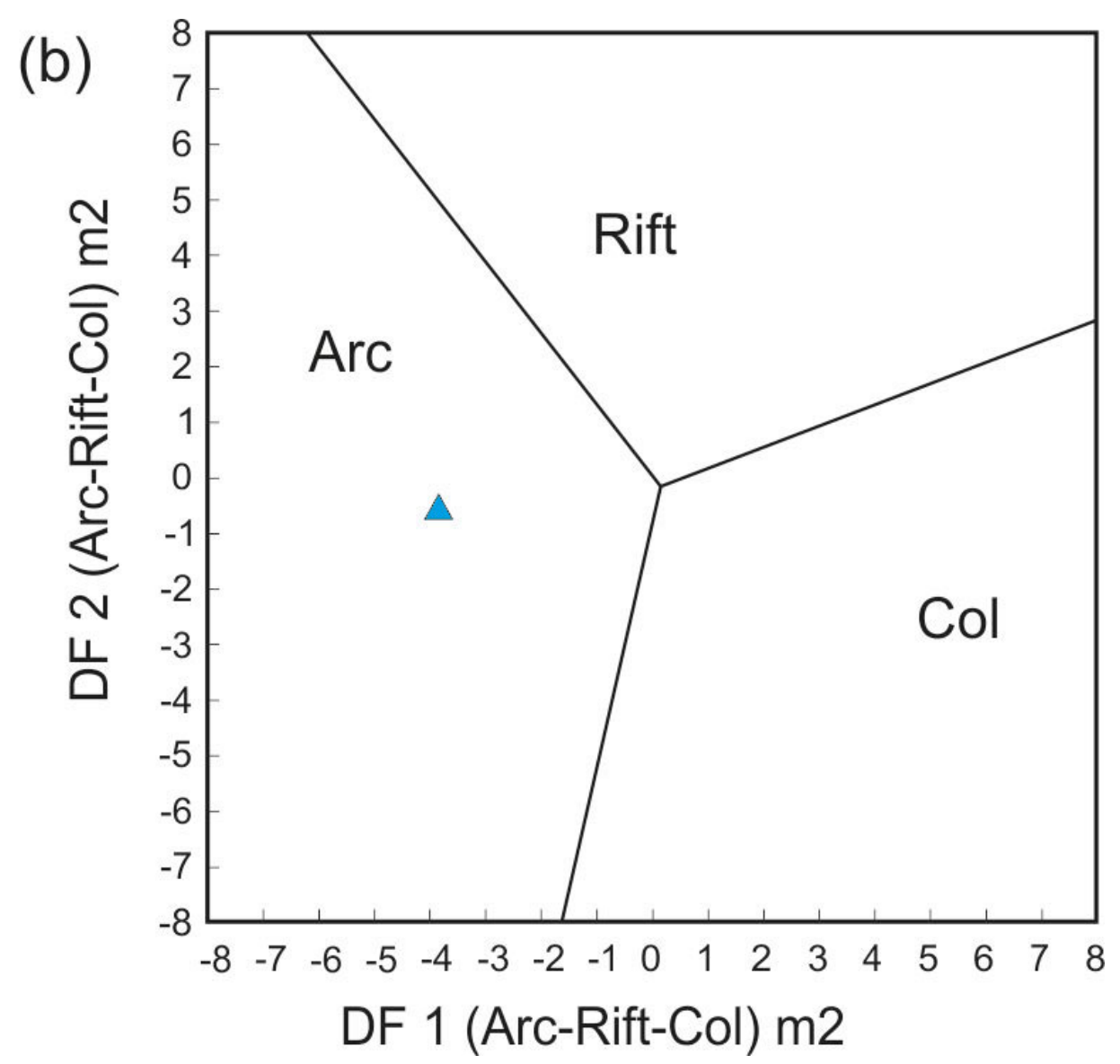

Figure 10 


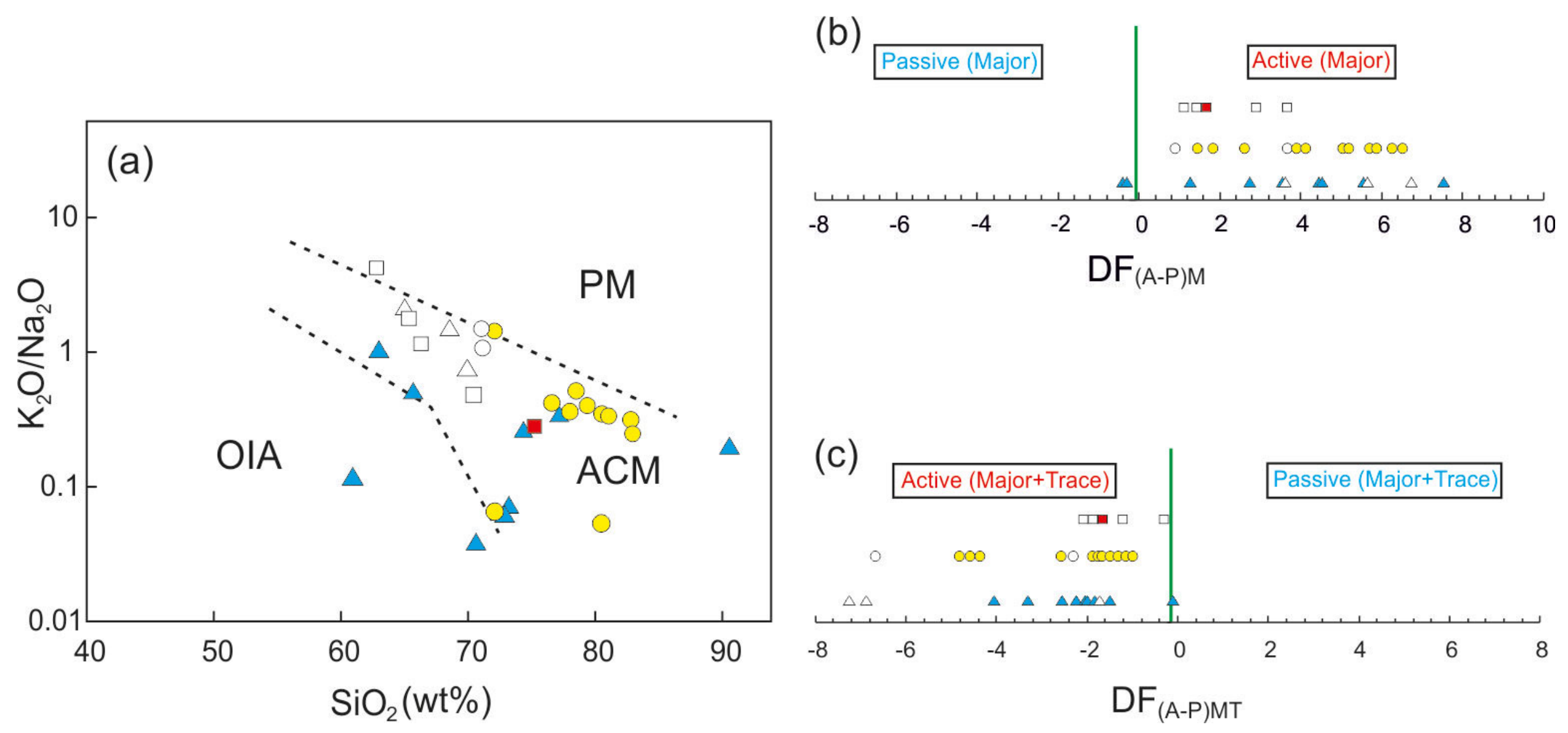

Figure 11 


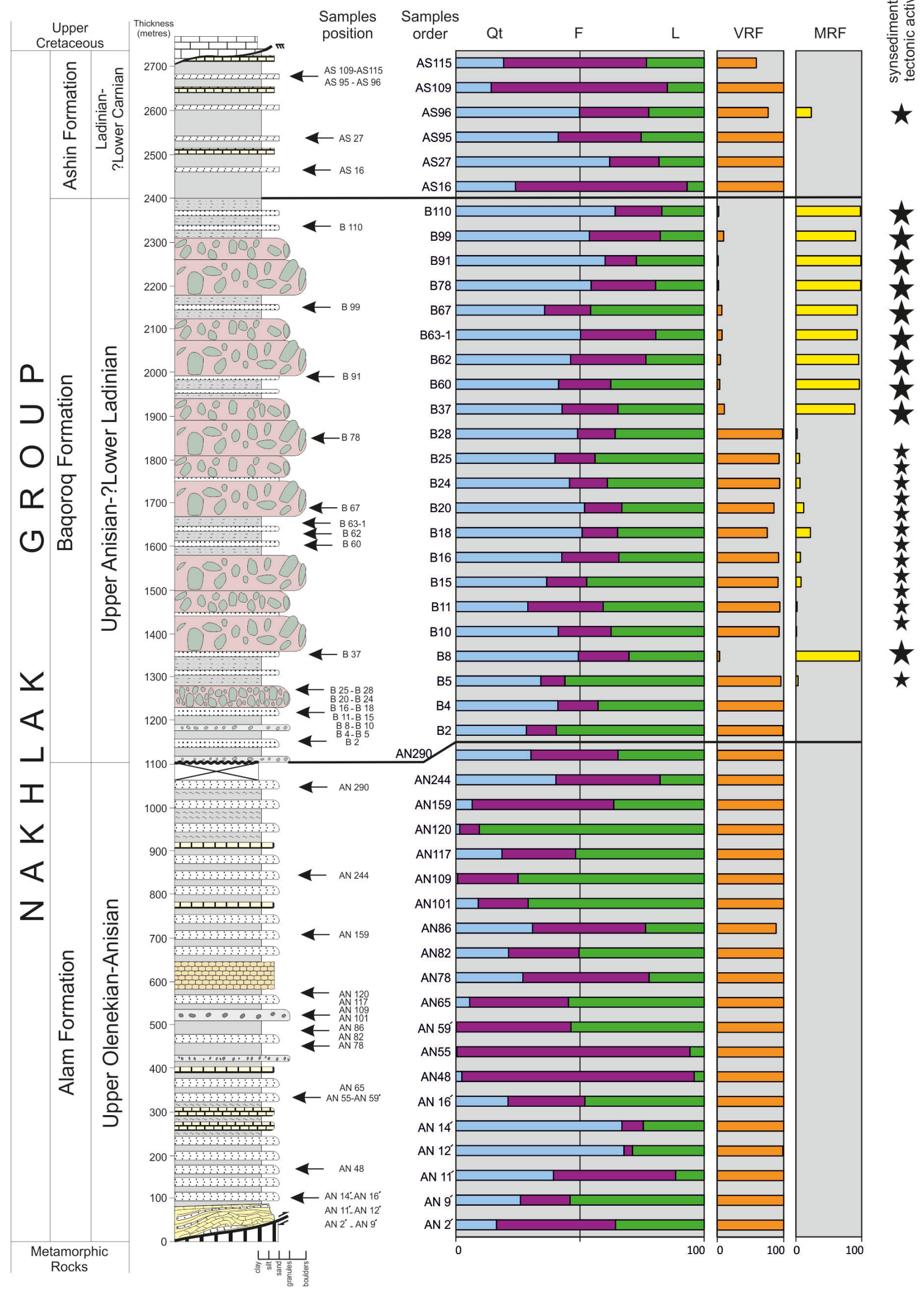

Figure 12 